\title{
The (Economic) Effects of Lay Participation in Courts - A Cross-Country Analysis
}

\author{
STEFAN VOIGT
}

CESIFO WORKING PAPER NO. 2365

CATEgory 2: Public CHOICE

August 2008

\footnotetext{
An electronic version of the paper may be downloaded

- from the SSRN website: www.SSRN.com

- from the RePEc website: - from the CESifo website: 


\title{
The (Economic) Effects of Lay Participation in Courts - A Cross-Country Analysis
}

\begin{abstract}
Legal philosophers like Montesquieu, Hegel and Tocqueville have argued that lay participation in judicial decision-making would have benefits reaching far beyond the realm of the legal system narrowly understood. From an economic point of view, lay participation in judicial decision-making can be interpreted as a renunciation of an additional division of labor, which is expected to cause foregone benefits in terms of the costs as well as the quality of judicial decision-making. In order to be justified, these foregone benefits need to be overcompensated by other - actually realized - benefits of at least the same magnitude. This paper discusses pros and cons of lay participation, presents a new database and tests some of the theoretically derived hypotheses empirically. The effects of lay participation on the judicial system, a number of governance variables but also on economic performance indicators are rather modest. A proxy representing historic experiences with any kind of lay participation is the single most robust variable.
\end{abstract}

JEL Code: B15, H11, H41, H73, K41, P51.

Keywords: economic effects of legal systems, judicial decision-making, trial by jury, jurors, lay assessors, constitutional economics, civil society, quality of governance, history of thought.

Stefan Voigt
MACIE (Marburg Center for Institutional Economics)
Barfüßertor 2
Germany - 35032 Marburg
voigt@wiwi.uni-marburg.de

The author thanks Anne van Aaken, Niclas Berggren, Lorenz Blume, Nils Carlsson, Michael Ebeling, Peter Egger, Wladimir Kraus, Sang Min Park, Janina Satzer, Michael Seebauer, Nguyen Quog Viet, Christof Voigt, and Jan Wagner for constructive critique and Nancy Sana for excellent research assistance. Voigt also thanks the participants of the CisoNet Workshop 4 "Markets and Civil Society in Europe", of the Social and Political Theory Seminar at the Research School of Social Sciences (Australian National University, Canberra), of the annual conference of the European Public Choice Society 2008 (Jena), the CESifo Delphi conference 2008 (Munich), the Ratio Institute workshop series (Stockholm) as well as the Comparative Law and Economics Forum 2008 (Madrid) for stimulating discussions. The paper was finished while its author was a Senior fellow at the Institute for Advanced Study in Greifswald. 


\section{The (Economic) Effects of Lay Participation in Courts - A Cross-Country Analysis}

Thus the jury, which is the most energetic means of making the people rule, is also the most efficacious means of teaching it how to rule well.

De Tocqueville, Democracy in America 1835, 128

\section{Introduction}

In many countries, lawyers and judges are among the most highly specialized professionals if the duration of their entire education is accepted as crude indicator. Countries that use lay participation (LP) in their courts deliberately forgo reliance on these professionals. Economists stress the advantages of specialization and the division of labor. They should, hence, be critical concerning LP as the expertise of some specialists remains explicitly unexploited. Many legal philosophers, on the other hand, have been downright enthusiastic about LP in judicial decision-making. Yet, their claims have never been put to an empirical test. It is the contribution of this paper to put the competing claims of economists and legal philosophers to such a test.

Both Hegel (1821) and Tocqueville (1835) dealt with the institution of the jury and praised it not for its advantages concerning the efficiency of adjudication but for its advantages for society in its entirety. At their time of writing, trial by jury existed primarily in England and its current and former colonies. France had just implemented some modified jury-model which spread from there to other countries on the continent as well as to other countries that were - directly or indirectly - influenced by the French, like some countries in Latin America. Today, we thus have a lot more empirical evidence concerning the functioning of juries within different economic, institutional, and cultural contexts. Hence, we can deal with their conjectures not only on theoretical but also on empirical grounds.

But this paper also makes a contribution to the intense debate on the possible effects of various legal systems which was kicked off by La Porta et al. (1999) who claim that many current differences in various aspects of government performance like degree of corruption, quality of local infrastructure and many more could be explained by drawing on the legal origin of the respective country's legal system. They distinguish between four such origins, namely British, Scandinavian, German and French. With regard to many aspects of government performance, they claim common law countries to come out first, whereas French legal origin is supposed to offer the worst prospects to a country. The authors thus do not analyze any specific differences with regard to the various legal systems. 
Trial by jury is often seen as one crucial component of the common law legal origin, whereas the use of lay assessors (lay persons jointly deciding together with professional judges) is often associated with the other legal families. Dealing with the question whether LP is a root cause for the different effects of various legal systems is, hence, a contribution to the debate on legal origins.

It is worth mentioning that LP has experienced a kind of renaissance in recent years: It has been re-introduced in countries as diverse as Japan, Kazakhstan, Russia and Spain. Our analysis will enable policy-makers to make more informed decisions on LP.

Two channels through which LP could have economic effects are distinguished: the first channel works via the effects of LP on the quality of the judiciary. If it helps to improve its quality, this ought to be reflected in economic outcomes such as investment, income and growth. The second channel works via the effects of LP on the political system at large. Legal philosophers have, e.g., argued that participation of the population in judicial decision-making would improve the information about the functioning of the entire political system but also its identification with the political system. LP would, in other words, increase the legitimacy of political systems which could have a number of positive economic effects, e.g. the need to police the population would be reduced - and monitoring costs could be saved accordingly.

A quantitative assessment of the various effects of trial by jury is surprisingly difficult as no cross-country data concerning the use of LP in judicial decisionmaking is readily available. One part of the paper is thus devoted to presenting a new dataset generated for this study. Many of the arguments of the legal philosophers that will serve as one source for our theoretical inspiration have been made with regard to trial by jury. Another form of LP namely lay assessors, only developed during the $19^{\text {th }}$ century. Although there are important differences between these two forms of LP, both forms are put to an empirical test. We are thus able to establish differences between the two approaches empirically. Overall, the effects of LP on the judicial system, a number of governance variables but also on economic performance indicators are rather modest.

The remainder of the paper is organized as follows: the next section presents a number of theoretical conjectures dealing with potential effects of LP both on the legal system narrowly delineated and beyond. Section three is an overview over quite a few aspects of LP. Section four describes the estimation approach as well as the data used. Section five discusses the results and section six concludes. 


\section{Hypotheses on the Effects of Lay Participation in the Judiciary}

This section serves to generate hypotheses on the possible effects of LP in judicial decision-making that are, at least in principle, empirically testable. In generating these hypotheses, we do not only rely on economic reasoning, but also heavily draw on a number of legal philosophers who have dealt with the topic for centuries. We propose to structure the hypotheses in a simple way: potential effects of LP on the legal system narrowly defined will be presented first. Only then do we turn to present a number of hypotheses dealing with potential effects of LP on the political system at large. The third, and final, step with regard to both channels is to conjecture about economic effects that could be caused via the two channels.

Before, we shortly discuss the issue whether the study should be constrained to trial by jury - or can be extended to LP in general, i.e. include both jurors and lay assessors. Jury members decide without a professional judge having the right to vote, whereas lay assessors vote together with one (or more) professional judges. Neither jurors nor lay assessors are experts in the law. If one is interested in analyzing the effects of LP, it thus seems to make sense to include both jurors and lay assessors into the analysis. It has been observed (Thamann 2000, 335) that lay assessors almost never outvote the professional judge(s) whom they decide together with although in principle, this is possible in many institutional settings. It has also been noted (ibid.) that lay assessors are a lot less active in court than jurors in the sense of asking questions etc. ${ }^{1}$ Some legal scholars - often originating from the U.S. - argue that institutions providing for the participation of lay assessors in judicial decision-making are an attempt to keep direct citizen participation in the court system under the control of professional judges (e.g. Munday 1993). The experiences in many formerly socialist states seem to corroborate that conjecture. Yet, our empirical knowledge concerning the effects of lay assessor participation is very scarce. This is precisely the reason why both forms of LP are included here as this allows us to systematically compare the differential consequences of these two different forms of LP. ${ }^{2}$

On the other hand, it has been observed (Kutnjak Ivkovic 1999, 18f.) that the absolute number of cases decided upon by lay assessors is presumably higher than that by juries. This is because civil law-countries do not have the institution of plea-bargaining which drastically reduces the number of cases actually decided upon by courts in many common law-countries. Furthermore, trial by jury and lay assessor courts are not the only institutions of lay participation in the judiciary: justices of the peace and lay magistrates that are frequently drawn on to adjudicate minor offenses are two other institutions. 
On the Effects of Lay Participation on the Quality of the Judiciary

An argument that is often advanced in favor of trial by jury is that juries would be better in finding facts than a professional judge (see, e.g., Duff 2000, 279). The fact-finding capacity could be better because jurors come from many walks of life and are thus people who have a lot of first-hand experience in the real world. ${ }^{3}$ As a hypothesis (\#1), one could formulate:

In countries with lay participation in judicial decision-making, mistakes in judicial fact-finding will occur less frequently than in countries without lay participation.

Given that this assumption is correct, an additional hypothesis drawing on Condorcet's jury theorem can be developed that claims that the higher the number of jurors participating in a specific case, the lower the probability of mistakes in judicial decision-making. If this hypothesis was true, then this would certainly be one important aspect of the quality of judicial systems. Pouring some water into the wine, one could, however, argue that jurors have fewer incentives than professional judges to care about the outcome of a case, precisely because it is a one-shot game: they do not strive for a career within the judiciary and have, hence, no incentives to build up a reputation as informed, law-abiding, fair decision-makers. This might lead them to pay less attention than professional judges to the outcome of a case (for the theory of low cost decisions, see Kirchgässner and Pommerehne 1993). ${ }^{4}$

A high probability of judicial mistakes can have important economic effects: if citizens are not able to produce expectations on the likely interpretation of legislation that have a good chance of turning out to be correct, their propensity to enter into contracts in the first place will be lower. This would imply less division of labor and lower incomes. This argument applies primarily to private - as opposed to criminal - law. When testing it empirically, it is, hence, important to take into account whether LP is confined to criminal law or extends into the private law realm.

If this were the main cause for the better fact-finding capacity of juries, this should be especially relevant in legal orders in which the position of a professional judge is acquired as a usual step in a career - such as Japan or Germany - because career judges become judges at a rather young age and have thus had less chance to make their own first-hand experience with the trustworthiness of statements etc.

$4 \quad$ But the opposite also appears plausible: precisely because being part of a court is no routine for jurors, they are more interested, pay more attention and so forth. 
Prima facie, relying on amateurs (jurors) rather than on professionals (judges) in order to make very important decisions (in the past jury verdicts were often decisions concerning life or death) seems an odd idea. But the English $18^{\text {th }}$ century jurist Sir William Blackstone (1791, book 3, chapter 23) wrote of the jury as "the glory of English law" and claimed that it put "a strong ... barrier between the liberties of the people and the prerogatives of the Crown." This has remained one of the central arguments in favor of trial by jury until today: it is the jury that protects the individual from the prerogatives of the state. The jury makes sure that individuals do not depend on the whim of the powerful state but that it is their peers who decide whether they have committed some crime or have reneged upon a contract. ${ }^{5}$

Here are some arguments in favor of the assumption that lay judges are less dependent on government than professional judges: they do not have an interest in a judicial career, which means that they do not have to behave cautiously out of reasons unrelated to the current trial. But jurors should also be more independent because the other two branches of government will have a hard time putting pressure on them: the threat of firing them is not credible which is also true for many other of the often-used instruments vis-à-vis professional judges, such as reducing their salary and the like. ${ }^{67}$ This might be particularly relevant in cases that are of direct interest to government such as those involving the opposition, critical journalists etc. This is why many legal orders that rely on trial by jury have allocated such offences to juries. Formulated as hypothesis \#2, it could read:

Blackstone's argument is based on the assumption that in the absence of lay participation, judges are under the tutelage of the executive. But there might be other institutions safeguarding the independence of the judiciary such as a fine-grained separation of powers or a high number of veto players. In order to prevent omitted variable bias, it is, hence, important to explicitly control for them.

6 On the other hand, it could be argued that government has more incentives to exert influence on the selection of lay judges. This will, hence, have to be controlled for in the empirical part. The more radical option, namely that government might try to do away with lay participation altogether, might be real but will not be extensively dealt with here as we are not endogenizing the institutions of lay participation.

Legal systems can be conceptualized like a value-chain: before courts act, a number of other actors have already acted, in criminal cases most likely the police as well as the prosecutors. It has been observed that in a number of countries (e.g. the former Soviet Union), judges almost always follow prosecutors. This tendency might also be curbed by the presence of lay judges and it played, indeed, a role in the discussion about the re-introduction of trial by jury in Japan (Kiss 2000, 356f.). This is, hence, another aspect of the conjecture that lay participation in judicial decision-making increases the independence of the judiciary. 
Countries with lay participation in judicial decision-making enjoy factually more independent judiciaries than countries without lay participation, c.p..

A factually independent judiciary reduces uncertainty - and increases predictability - if it increases the likelihood that formal legislation gets factually implemented. If it functions like this, citizens will develop a longer time horizon which will lead to more investment in physical capital but also to a higher degree of specialization, i.e., to a different structure of human capital. All this means that JI is expected to be conducive to economic growth. Feld and Voigt $(2003,2006)$ present a measure of de facto JI and show that it is highly significant and robust for explaining differences in growth rates in a sample of more than 70 countries. ${ }^{8}$

A similar argument has been advanced by Adam Smith in his "Lectures on Jurisprudence" (1776/1982): "Another thing which curbs the power of the judge is that all causes must be try'd with regard to the fact by a jury. The matter of the fact is left entirely to their determination." Smith seems more specific than Blackstone: for him, trial by jury is primarily a means to curb the power of the judge - and not the state at large. Yet, both have something similar in mind: the judge is often seen as a representative of the powerful state against which people who appear in court are ill-protected. Professional judges who are independent from the other branches of government as well as from the conflicting parties might misuse their factual independence by remaining uninformed, following their own ideologies, becoming lazy or even corrupt. It is assumed that one wants judges to be accountable to the law - and not, at least not directly, to the other branches of government, the conflicting parties or even the population at large. ${ }^{9}$ It can be argued that juries are a potential means to make professional judges more accountable: if juries force the judges to explain the central content of the law to

JI implies that judicial decision-makers can expect their decisions to be implemented regardless of whether they are in the (short-term) interest of other government branches upon whom implementation depends. It would further imply that judges and lay decisionmakers - if there are any - do not have to anticipate negative consequences as the result of their decisions, such as (a) being expelled, (b) being paid less, or (c) being made less influential.

9 A judiciary can be said to be accountable to the law if judicial decision-makers have incentives to apply the letter of the law - and not the wishes of other actors. Voigt 2008 deals with the relationship between judicial independence and judicial accountability and argues that they do not need to be conflicting but can, even, reinforce each other. 
them in a comprehensible manner, the possibility that judges can shield themselves behind complicated language is reduced. ${ }^{10}$

Based on these arguments, one could derive hypothesis \#3:

Countries that use lay persons in judicial decision-making are expected to experience higher levels of judicial accountability than countries that do not, c.p..

Transparency is often said to be a precondition for accountability. The effect of LP on transparency is, however, somewhat ambivalent. On the one hand, it can be argued to be higher with LP as a professional judge usually has to explain the relevant law to the jurors. Often, the decision is taken after the jurors have answered a list of very detailed questions. These measures can be said to increase the transparency of judicial decision-making vis-à-vis the population at large. On the other hand, the reasoning for the verdict is frequently not published which makes the decision-making process of juries rather intransparent.

Accountability of judicial decision-makers to the law - and not to specific persons no matter whether they belong to the other branches of government or appear in court - implies that there is less room for "buying decisions", i.e. for corruption within the judiciary. Regarding pressures put on by the accused party (or the contracting parties in case of a private law case), there has been some disquietude that jurors could be intimated by people involved in organized crime. This can, of course, not be excluded but the threat does not appear to be more serious than with regard to professional judges. The possibility of being bribed is another issue. It can be argued that the probability of lay judges being bribed should be lower than that of professional judges: (i) there is a lot more persons to be bribed, (ii) it is a one-shot game and establishing relationships thus extraordinarily costly, and (iii) the identity of the jurors is often known with very short notice only.

These considerations can be summarized as hypothesis \#4:

The U.S. is one of the few countries in which judges are subject to periodic elections. This induces a very special kind of accountability, namely to the constituency rather than to the law. It almost suggests itself to construct a connection between the necessity of re-election and the immense importance of trial by jury in the U.S.: trial by jury is a good means of making the professional judges also accountable to the law. Re-election necessities are not evenly distributed over the U.S. It would be fascinating to inquire whether the relevance of juries is negatively correlated with re-election requirements. 
In countries with lay participation in judicial decision-making, the judiciary should, c.p., be less corrupt than in countries without lay participation.

A number of follow-up effects can be expected to occur: if the degree of corruption within the judiciary is low, then judges will be less tolerant regarding corruption in other government branches and the overall level of corruption ought to be lower. At the end of the day, low corruption levels decrease uncertainty and improve predictability so that one can expect economic effects like higher investment levels to occur. High degrees of corruption have, indeed, been shown to distort economic growth and development (Mauro 1995).

Legislation and the judicial decision-making based on it need to reflect the coordination problems of those subject to legislation. It is at times argued that the common law is better in picking up changing needs than civil law because judges would be closer to the real problems than legislators. If this argument is correct, it might even be amplified if LP is part of the judicial system because lay judges might be closer still to the real problems than professional judges. Conjectures similar to this can, indeed, be found in the literature on LP. Munday $(1993,221)$, e.g., argued that jury trials allow "justice to be done in individual cases where the jury considers that it would be unduly harsh to adhere strictly to the letter of the law." This is closely connected with another argument (ibid.) that stresses the higher degree of accountability of the state vis-à-vis its citizens: if laws appear to be inadequate or patently out-of-step with the views of 'society', the jury could interpret the law with flexibility thus making it compatible with the values and norms of society.

Ascertaining whether judicial decision-making is in line with the problems real people have is no mean feat empirically. We thus propose the following hypothesis \#5 that can be put to an empirical test:

The quality of justice perceived by citizens is higher with lay participation than without, c.p..

This hypothesis only holds if we have good reasons to assume that (i) lay judges are more in tune with current coordination problems than both professional judges and legislators. In addition, the hypothesis is not unproblematic: legal certainty can suffer as a consequence of some lay judges being less harsh than the law permits. It can also be problematic because such decision-making would allow for the non-congruence between legislation and decision-making which could lead to a deterioration of predictability with a number of adverse economic effects spelled out above. In common law, there is a systematic place for judicial rule-making. 
This is not the case in civil law which implies that this effect could be worse in civil law countries than in common law ones.

But people who act contrary to established conventions might be less secure in the hands of jurors who might represent well-established conventions. Taking the argument one step further, one might even argue that trial by jury is an institution which could be a hindrance to innovation. It could furthermore be argued that trial by jury inheres the danger of transforming itself into an instrument for redistribution. A jury representing the median income earner might decide to put a hefty fine on someone simply because of his being more wealthy. Trial by jury could thus also lead to the exploitation of minorities by majorities.

To sum up: the five hypotheses developed with regard to the effects of LP on the legal system thus all point in one direction: various aspects of the judiciary should be better with than without LP. At the end of the day, this ought to be reflected in economic variables such as income or growth. We now move on to the second battery of hypotheses that deal with the potential effects of LP on the political system at large.

\section{On the Effects of Lay Participation on the Political System at Large}

We began the section on the effects of LP on the judiciary by drawing on Blackstone and Smith. Of course, the arguments advanced by Blackstone carry over to the political system at large - and also remind us that the distinction used here is not entirely watertight.

Among legal philosophers, Tocqueville (1835) is probably the one who is most explicit in stressing potential effects of LP on the political system. He makes a distinction between the jury as (1) a political institution and (2) a judicial institution and claims the former to be a lot more important than the latter: although it has an important impact on the outcome of cases (judicial institution), its impact on "the destinies of society at large" (political institution) is even more important. As a political institution, it would be an extremely important instrument to realize people's sovereignty. The quality of the jury as a judicial institution is evaluated rather critically. It would go back to times with a lot less complexity than today. ${ }^{11}$

According to Tocqueville, the institution of trial by jury would teach people equity, it would teach people that they cannot escape from being responsible for 
their own actions, it would teach everybody that they have duties vis-à-vis society, and it would subdue personal egoism, which he portrays as "the deap-seated evil of society."

The jury contributes powerfully to form the judgment and to increase the natural intelligence of a people; and this, in my opinion, is its greatest advantage. It may be regarded as a gratuitous public school, ever open, in which every juror learns his rights, enters into daily communication with the most learned and enlightened members of the upper classes, and becomes practically acquainted with the laws, which are brought within the reach of his capacity by the efforts of the bar, the advice of the judge, and even by the passions of the parties. ${ }^{12}$

Formulated as hypothesis \#6, these arguments could read:

In countries that use trial by jury, the population will be more knowledgeable concerning its legal order than in countries that do not use trial by jury.

Greater knowledge of and familiarity with one's own legal system can have economic consequences like relying on the legal system in a more informed and adequate way.

Summing up his argument on trial by jury, Tocqueville writes that this institution would be the most effective means not only to let the people rule but also of teaching the people how to rule. This could mean that the existence of the jury increases the quality of government because large parts of the population have been involved in a "training course". Hypothesis \#7 could thus be:

Countries that use trial by jury should experience a higher general quality of governance.

Here again, economic variables are conjectured to be influenced: the quality of governance can be interpreted as an input into production and exchange; it should make production factors more productive and, hence, contribute to total factor productivity. If its quality is higher (or the cost of its provision lower) as a consequence of LP, this should be reflected in higher total factor productivity, c.p..

Recent empirical evidence suggests that the amount of information that citizens acquire about their own political system is indeed endogenous to political institutions: Benz and Stutzer (2004) show that the amount of knowledge that citizens of various EU memberstates command about the EU institutions is determined by the absence/presence of referendums on European issues: citizens in states that have held referendums on European issues are significantly better informed than citizens of states that have not held referendums. 
It is noteworthy to stress some of the differences between Blackstone's and Tocqueville's arguments. Whereas Blackstone - and many, probably most, others dealing with trial by jury - stresses the function of the jury as controlling statepaid judges, Tocqueville sees (American) judges as sharing a certain desirable spirit, which would be adopted by large parts of the population. Economically speaking, it could be said that Tocqueville advances an argument in favor of a low degree of division of labor: he does not want to rely exclusively on professional judges but wants to include other parts of society which is an ideal within the notion of civil society: society itself is responsible for running the state, here the judiciary. Tocqueville argues that trial by jury seems to reduce the power of professional judges. But this would only be seemingly so: by being in contact with professional judges, jurors would learn of their spirit and even develop some awe for them.

Almost one hundred years before Tocqueville, another Frenchman described some features not of the American but of the British political system. Montesquieu (1748) popularized the structure of the English political system on the continent. He famously described the judiciary as "en quelque façon nul". Concerning the appointment of judicial competence, he argued (XI ${ }^{\text {th }}$ book, $6^{\text {th }}$ chapter) that it should be exercised by people that "are chosen according to law for specific times of the year from among the entire population. They ought to form a tribunal, which only exists as long as necessity demands." Judicial competence should hence not be allocated to a tenured senate. This would reduce the amount of anxiety the population feels for the judiciary because juries are connected neither with a certain rank nor a certain profession. ${ }^{13} \mathrm{He}$ continues to advance reasons in favor of trial by one's peers. Spelt out as hypothesis \#8, this conjecture can be formulated as:

In countries with trial by jury, fear of the judiciary is substantially lower than in countries without trial by jury.

Montesquieu evaluates his conjecture positively. Yet, it seems more difficult to evaluate the economic consequences of this conjecture: does the absence of fear induce people to take more cases to court? Would it, in other words, reduce the likelihood of settling disputes out of court? Could that not even be a negative effect because more resources will be spent on the courts? With regard to criminal to it, people can also derive utility from being subject to a fair process even when the final decision is against them (see Frey et al. 2004). 
law, could absence of fear not entail the danger of more crimes? Or can "absence of fear" also be read as "trust in the governance of the court system"? If this interpretation turned out to be true, then people might be inclined to enter into more contracts in the first place which could, in turn, lead to better economic performance. ${ }^{14}$

In his Philosophy of Law, Hegel (1821) also advances a number of arguments in favor of trial by jury. He argues ( $\S 218$ ) that in civil society (bürgerlicher Gesellschaft), a crime is not only an injury of something subjectively infinite (subjektiv-unendlich), but of a general concern (allgemeine Sache). It is the public at large that prosecutes criminals ( $\S 220)$, the penalty being more than simply revenge but "(s)ubjectively, it is the reconciliation of the criminal with himself, i.e. with the law known by him as his own and as valid for him and his protection; when this law is executed upon him, he himself finds in this process the satisfaction of justice and nothing save his own act."

According to Hegel, this would, however, be doomed to fail when the suspect is entirely dependent on professional judges because that would mean the exclusion of society from jurisdiction. He formulates his ideas concerning the jury in $\S 228$ :

Owing to the character of the entire body of the laws, knowledge both of what is right and also of the course of legal proceedings may become, together with the capacity to prosecute an action at law, the property of a class which makes itself an exclusive clique by the use of a terminology like a foreign tongue to those whose rights are at issue. If this happens, the members of civil society ... are kept strangers to the law, not only to those parts of it affecting their most personal and intimate affairs, but also to its substantive and rational basis, the right itself, and the result is that they become the wards, or even in a sense the bondsmen, of the legal profession.

Hegel thus argues that the members of (civil) society ought to recognize that the administration of justice is part of their affairs. He refuses to accept the argument that professional judges could make decisions a lot more efficiently (ibid.):

It may be the case that if the administration of justice were entirely in the hands of professional lawyers, and there were no lay institutions like juries, it would in theory be managed just as well, if not better. It may be so, but even if this possibility rises by general consent to probability, or even certainty, it still does not matter, for on the other side there is always the right of self-consciousness, insisting on its claims and dissatisfied if laymen play no part.

"Absence of fear" is hard to ascertain empirically, its consequences are even theoretically unclear. In the empirical section, we restrict our attention to the bivariate correlation between the use of lay participation and the number of reported crimes. 
Unfortunately, it remains somewhat unclear what exactly Hegel has in mind when he writes of the better management of justice. At least two interpretations seem possible: It could mean that professional judges and lay juries come to basically identical decisions, yet professional judges need less resources for their decisions. Economists would then claim that the administration of justice by professionals is more efficient. This interpretation draws on a rather narrow interpretation of efficiency and Hegel would presumably quarrel with it. For him, the "selfconsciousness" is so important because he sees it as the only way to induce a society-wide discourse about right and wrong, which is a precondition for the general acceptance of the law. If the law is generally accepted in society, fewer people would violate it, fewer resources will have to be spent on the administration of the entire system and at the end of the day, self-consciousness increases efficiency, now more broadly delineated. Turned around, one could say that no legal system which is not generally accepted can ever be efficient. Hegel thus believes that the apparent trade-off between the efficiency of the administration of justice on the one hand and the self-consciousness on the other is only a superficial trade-off. Hegel seems to pronounce lexicographic preferences: first, the necessity of self-consciousness has to be satisfied. Only then will Hegel start to think about the management of the judicial system.

But this is only the first of at least two possible interpretations. The second one would be that the better administration of justice through professional judges means that the likelihood that professional judges come to erroneous decisions is lower than that of lay juries. If that were what Hegel had in mind, his normative statement in favor of lexicographic preferences would be highly controversial: it could mean that he would accept a falsely declared death penalty for the sake of self-consciousness. Yet, this interpretation seems unlikely because it entails the danger of being self-contradictory: chances that a legal system will be generally accepted although the probability of wrongful conviction is high appear to be rather slim. Trying to focus on the more plausible interpretation of Hegel, we can now present hypothesis \#9:

Trial by jury induces a discourse concerning right and wrong onto society which, in turn, does not only improve the knowledge concerning the legal system but also increases the legitimacy of the entire political system.

The close connection between this hypothesis and the one dealing with the higher degree of knowledge advanced by Tocqueville (hypothesis \#7) is apparent. A high degree of legitimacy is supposed to have a number of economically relevant consequences: If a political system enjoys a high degree of legitimacy, it will 
almost by necessity also be a stable system. Stability is, in turn, a precondition for high investment rates. A high degree of legitimacy is, hence, assumed to be strongly correlated with high investment levels. Another economically relevant consequence of a high degree of legitimacy is concerned with the size of the budget as well as its composition: a high degree of legitimacy is assumed to be correlated with lower degrees of tax resistance. This means that less resources need to be spent for monitoring the tax paying behavior of citizens. High degrees of legitimacy are, hence, expected to be correlated with smaller overall budget and a composition of the budget that allows higher degrees of productivity. ${ }^{15}$

To sum up: we have developed five hypotheses concerning the effects of LP on the judicial system, and four hypotheses concerning the effects on the political system. All of them contain the conjecture that LP improves either the judicial or the political system. Yet, some political philosophers have argued that the effects of LP on the judicial system could be negative. This implies the possibility of a trade-off. Whether it exists and what effect dominates is the subject of an empirical test. Before getting to the empirical test, the next section serves to present an overview of LP in the world today.

\section{An Overview over Lay Participation}

It is the purpose of this section to provide an overview of the various institutions currently used to make lay people participate in judicial decision-making. Unfortunately, no dataset containing the variables that we are interested in here was readily available. This is why we decided to construct a questionnaire which was sent to all the ministries of justice for which an address could be found. After some 2 months, a first round of reminders was sent out via e-mail. In addition to the ministries of justice, the questionnaire was also sent via e-mail to a number of other country experts such as judges, law professors, lawyers, but also activists from non-governmental organizations. For filling in the questionnaire, the country experts did not have to make personal evaluations of the situation in their country, but were asked to simply give information on the legal structure of the judiciary.

Whether this hypothesis holds true does, however, depend on other hypotheses being correct. Hypothesis number 1 claimed that the probability of wrong decisions would be lower in legal orders that rely on juries. If this hypothesis proves to be wrong, the effects of the jury on the legitimacy of a legal order are expected to be ambivalent: the participation of civil society as such could lead to an increase in the legitimacy of the judicial system, whereas the low quality of the decisions brought about by the jurors could reduce its legitimacy, the net-effect would then be subject to evaluation. 
The questionnaire is, however, not the only source of information relied upon here. For some of the more general variables, readily available sources were used in addition to the questionnaire. Many questions were not answered by all respondents. The maximum number of countries covered by this survey is 80 . The questionnaire is documented on our homepage. Note that the coding contained there was not contained in the version of the questionnaire sent to the country experts.

Not all questions contained in the questionnaire are explicitly mentioned and described here. This is due to the fact that most questionnaires were filled in only partially. Questions for which the number of replies are insufficient to run regressions are generally not discussed here.

In the introduction to the questionnaire, a lot of emphasis was put on the distinction between jurors on the one hand and lay assessors on the other. Nevertheless, the first question simply inquires whether the country knows any form of LP, thus including both types. 27 countries do not know any form of LP, whereas 53 countries covered do. Of the countries covered, 27 draw on juries, whereas 35 rely on lay assessors. 13 countries rely on both jurors and lay assessors (appendix 2 contains some more details).

Usually, constitutions can only be changed by supermajorities. If the foundation for LP can be found in the constitution, this institution is entrenched - and should be more difficult to abolish than if it were not mentioned in the constitution. This variable allows us to test whether constitutionally entrenched juries (lay assessors) have more significant effects than juries (lay assessors) that are not entrenched. LP is explicitly mentioned in some 20 constitutions in one form or another.

Trial by jury is often confined to specific cases. Historically, cases in which the government could have a special interest have often been delegated to juries such as cases involving freedom of the press. The most important question from an economic point of view is, however, whether participation of lay judges is confined to criminal cases or extends to civil cases as well: the number of private contracts, the ensuing degree of specialization etc. are unlikely to be heavily influenced by LP in criminal law cases, but might be influenced by LP in private law cases. Questions 4 and 28 contain information on the matter: The vast majority of legal systems is confined to criminal cases. Among the criminal cases, jurisdiction is usually confined to very serious crimes and the jurisdiction is determined either by the minimum sentence that would apply were a suspect declared guilty or by the court in front of which the case is tried (and these two criteria usually go hand in hand). There seems to be some difference between the 
"other competences" of lay judges, depending on whether the legal system knows a jury system or draws on lay assessors: in the former case, issues of freedom of the press have, at least historically, played some role. In the latter case, labor disputes, but also social security issues and family law issues seem to have played a greater role. ${ }^{16}$

Question five deals with the percentage of all criminal/non-criminal cases that are dealt with by lay judges. The answers would thus allow us to assess the relevance of both kinds of LP quantitatively. It might well be that in some countries the institution of LP survived formally but is factually never or close to never used. Unfortunately, we only received information on these numbers from 21 countries which makes it almost impossible to use the data for an econometric analysis. Nevertheless, it is interesting that in Senegal, all criminal cases are dealt with by juries (for Finland it is $72 \%$ ). Although the average is close to ten percent, the mode for this variable is 0 (including answers like "very close to zero"). The combination between juries and non-criminal cases is encountered most frequently in the Philippines where $25 \%$ of non-criminal cases are tried by juries. Here, the average is $1.5 \%$ with the mode still being 0 . For lay assessors both modes (for criminal as well as for non-criminal cases) are also 0 , yet the averages (for all they are worth) are higher, namely 22.83 and $15.65 \%$ respectively. In criminal cases, it is, again, Senegal that takes the lead with $100 \%$, in non-criminal cases it is Vietnam (100\%) and Turkey $(70 \%)$.

The questionnaire also deals with the historical use of LP. We believe this to be potentially important because a country that relied on LP for a century or so might still experience effects from that period today as LP might have shaped traditions on how judges behave vis-à-vis suspects or, more generally, how representatives of the state deal with citizens. The historical section provides information on two different aspects, namely whether the country under consideration relied more on juries or lay assessors (question 27) and whether LP was restricted to criminal law or also extended to private law (question 28). With regard to both criminal and private law, it asked when the competence was first created and when it was abolished, if applicable.

In order to get a more complete impression of the various forms of LP and its diffusion around the world legal systems, we now describe a number of bivariate lay assessors applies to those "matters of customary law that judges do not understand." 
correlations with historical, political, legal and sociological traits (table 1). The various forms of LP are represented as dummy variables. Countries in the first column are coded 1 if they currently have any kind of LP. Later on, a more specific question will be of interest, namely whether there are systematic differences between countries that rely on different forms of LP. The other columns contain dummy variables for these more specific forms. It will, of course, be of particular interest to compare the effects of trial by jury (column 2) with those of lay assessors (column 3). However, the general impression is that most correlations are not particularly high.

It is often taken for granted that common law countries rely more heavily on juries whereas civil law countries tend to rely more on lay assessors. The signs of the respective coefficients in row 1 are in accordance with this assumption, yet they are far from being significant. The jury dummy even has the "wrong" sign when it is correlated with another dummy which is coded 1 for all countries that used to be British colonies. ${ }^{17}$ This changes when the forms of LP are correlated with the percent of the population speaking English (row 3): now, the correlation with juries is quite significant.

The next row looks at possible correlations between LP and ethno-linguistic fractionalization. In highly fractionalized societies in which members of the various fractions do not trust each other, LP might be a problem. The result shows that the two are almost perfectly uncorrelated. This is also the case with regard to more specific measures focusing on one aspect of fractionalization (ethnicity, religion, language) alone (not reported in the table).

Among institutional variables, the correlation between LP and presidential systems (row 5) is noteworthy: presidential systems are significantly less likely to have any kind of LP (with the exception of justices of the peace).

The next group of variables (rows 6 through 10) does not focus on formal institutions, but rather on policy outcomes such as the level of realized political rights, civil liberties or democracy tout court. Two general observations stand out: first, LP is correlated with better performance in all dimensions, albeit often not

The correlation between countries that belong to the common law tradition and that also used to be British colonies is high, but not perfect. Countries that used to be British colonies but are not grouped as belonging to the common law family are Cambodia, Egypt, Jordan and Mauritius. Conversely, countries that belong to the common law tradition but that were not British colonies are Ireland, Namibia, Nepal, Thailand, the U.K. and the U.S.. 
very significantly. Second, the correlation of these indicators with juries is always higher than with lay assessors.

Another dimension in which countries with lay assessors seem to be doing better than countries with trial by jury is the general level of trust. Many studies have shown that higher levels of trust are conducive to economic development because the costs of transacting are lower as many contracts need to be formalized or formalized to a lesser degree than in environments where people do not trust each other. ${ }^{18}$ Two more interesting results deal with the correlation between LP and the evinced interest in politics: people in countries relying on lay assessors are significantly less interested in politics than people in countries with trial by jury.

Table 1: Bivariate Bravais-Pearson correlations

\begin{tabular}{|c|c|c|c|c|c|c|}
\hline & & $\begin{array}{l}\text { All Kinds of } \\
\text { Lay } \\
\text { Participation }\end{array}$ & Juries & $\begin{array}{l}\text { Lay } \\
\text { Assessors }\end{array}$ & $\begin{array}{l}\text { Justices of } \\
\text { the Peace }\end{array}$ & $\begin{array}{l}\text { Lay } \\
\text { Magistrate }\end{array}$ \\
\hline 1 & Common Law (Dummy) & 0.001 & 0.090 & -0.090 & 0.008 & 0.216 \\
\hline 2 & British Colonial History (Dummy) & -0.166 & -0.055 & -0.086 & -0.140 & 0.071 \\
\hline 3 & Eng Frac* & 0.207 & 0.382 & -0.110 & 0.376 & 0.210 \\
\hline 4 & Ethno-linguistic fractionalization & -0.001 & -0.083 & 0.055 & -0.030 & 0.158 \\
\hline 5 & $\begin{array}{l}\text { Presidential systems }(=1 ; \text { others }= \\
0)\end{array}$ & -0.338 & -0.146 & -0.327 & 0.169 & -0.107 \\
\hline 6 & $\begin{array}{l}\text { Political Rights }(1-7 ; 1=\text { highest } \\
\text { degree) }\end{array}$ & -0.249 & -0.313 & -0.104 & -0.041 & -0.012 \\
\hline 7 & $\begin{array}{l}\text { Civil Liberties }(1-7 ; 1=\text { highest } \\
\text { degree) }\end{array}$ & -0.185 & -0.280 & -0.055 & & -0.012 \\
\hline 8 & $\begin{array}{l}\text { Freedom of the Press }(0-100 ; 0= \\
\text { highest degree })\end{array}$ & -0.282 & -0.344 & -0.166 & -0.078 & -0.049 \\
\hline 9 & De facto JI (0-1; 1 highest degree) & 0.169 & 0.240 & 0.227 & 0.214 & 0.161 \\
\hline 10 & $\begin{array}{l}\text { Level of Democracy (Polity IV; }-10 \\
-10 ;-10 \text { "perfect autocracy") }\end{array}$ & 0.184 & 0.204 & 0.072 & 0.100 & -0.013 \\
\hline 11 & $\begin{array}{l}\text { Confidence in the Legal System } \\
\text { (sum of "complete" and "great } \\
\text { deal" of confidence in } \% \text { ) }\end{array}$ & -0.180 & 0.088 & 0.142 & -0.057 & -0.254 \\
\hline 12 & $\begin{array}{l}\text { Power Distance Indicator ( } 0 \text { to } \\
\sim 100 \text {; higher values indicating } \\
\text { higher power distance) }\end{array}$ & -0.088 & -0.263 & -0.038 & 0.356 & -0.154 \\
\hline 13 & General level of trust (WVS) & -0.116 & -0.373 & -0.013 & 0.013 & 0.085 \\
\hline 14 & Interest in politics (WVS) & -0.131 & 0.166 & -0.413 & 0.157 & 0.055 \\
\hline 15 & Follow Politics Closely (WVS) & -0.012 & 0.052 & -0.449 & 0.284 & 0.189 \\
\hline
\end{tabular}

* Fraction of the population speaking English;

The bivariate correlations are usually rather modest. Yet, they contain some clues about possible relationships. But in order to analyze them systematically, we need to move on to multivariate regression analysis which we do now. 


\section{Data and Estimation Approach}

After having developed a number of hypotheses (section two) and presented our dataset (section three), we now move on to describe our estimation approach. In order not to overburden the paper, we confine ourselves to testing four hypotheses explicitly, namely the influence of LP in judicial decision-making on (1) the factual independence of the judiciary, (2) the perceived degree of corruption in the judiciary, (3) government efficiency (proxied for not only by the variable "government efficiency" from the Governance Indicators provided by the World Bank but also by the Corruption Perceptions Index produced by Transparency International as well as the variable "Graft" - also from the World Bank), and (4) on labor as well as total factor productivity. ${ }^{19}$ The first two hypotheses thus refer to the effects of LP on the functioning of the judicial system, the last two hypotheses refer to very broad effects on the economy at large.

All models can be described with the following equation:

$$
\mathrm{Y}_{\mathrm{i}}=\alpha+\beta \mathrm{M}_{\mathrm{i}}+\gamma \mathrm{LP}_{\mathrm{i}}+\delta \mathrm{Z}_{\mathrm{i}}+\varepsilon_{\mathrm{i}}
$$

where $Y_{i}$ represents any of the outcome variables just mentioned in country i. $M_{i}$ is a vector of standard explanatory variables of country $i$; these differ depending on the dependent variable used. $L P_{i}$ is the measure of LP in country $i, Z_{i}$ is a vector of additional explanatory variables in country $i$ that are introduced to check the robustness of the respective model under consideration and to consider the interaction with the institutional and socio-economic environment of a country, and $\varepsilon_{i}$ is an error term.

For every hypothesis, 13 different variables proxying for LP are used. These 13 variables can be divided into three groups, namely

(1) dummy variables for the current use of LP (all kinds of lay participation [LAYP], based on juries [JURY] or on lay assessors [LAYASS]),

(2) the anchoring of LP in the current constitution of a country (LAYPCON, JURYCON and LAYASSCON) and

(3) historical reliance on LP (LAYPHIS, JURYHIS, LAYASSHIS; HISCRIM (coded 1 if the competence of LP was restricted to criminal cases), HISCIV (coded 1 if it also extended to civil cases), TIMECRIM (number of years that competence with regard to criminal cases has been or was in place), 
WEIGHTIME (number of years if competence still exists; number of years divided by two if it has been abolished).

The cross section analysis is performed by the simple OLS technique while inference is based on t-statistics computed on the basis of White heteroscedasticity consistent standard errors. Scholars of LP have often stressed that beneficial effects were to be expected only given that specific preconditions were met. Jeary $(1960 / 1)$ mentions three conditions that need to be fulfilled if trial by jury is to function properly: (1) society must be racially, culturally, linguistically, and religiously homogeneous; (2) members of society must be sufficiently educated to understand their responsibilities as jurors; (3) members of juries must generally agree with the laws which they are supposed to enforce. Adding to this list, it seems plausible to assume that (4) very high degrees of inequality could inhibit the beneficial use of a jury, as some jurors might be motivated by aspirations of redistribution.

Some of these preconditions can easily be controlled for by respective proxies. The homogeneity in terms of ethnicity and the like (condition 1) is taken into account by using an indicator which explicitly measures a mixture between ethnic, religious, and linguistic fractionalization. The degree of education (precondition 2 ) is controlled for by the number of years that people spent in school. Whereas we do not know of any proxy for the third precondition, inequality in terms of income or wealth is controlled for by using the Gini-coefficient. We propose to work with interaction effects in ascertaining the relevance of the conditions for the beneficial functioning of LP empirically.

\section{Estimation Results}

The null-hypothesis that LP does not have significant effects on any of the four groups of dependent variables tested here cannot be rejected in many cases. We report primarily those estimates in which LP has at least some effect.

First, we are interested to know whether LP has any effects on de facto Judicial Independence, the idea being that lay judges are more independent from government to begin with - and this would improve the overall level of factual independence of the judiciary from the other branches of government. ${ }^{20}$ As the Mvector, we use the "democratic age" of a country (the older it is, the higher its de 
facto JI), the degree of checks and balances realized in 1995 (the higher its level, the higher the factually realized level of JI), and the degree of democracy (again, the higher the factually realized level of democracy, the higher the factually implemented level of JI). These three variables "explain" more than a third of the variation in the levels of de facto $\mathrm{JI}$ observed in 76 countries for which information is available (Adj. $\left.\mathrm{R}^{2}: 0.3397\right)$. The estimates are displayed in table $2 .{ }^{21}$ If this benchmark is augmented with any one of the three basic LP dummies,

Table 2: Lay Participation and De Facto Judicial Independence

\begin{tabular}{|c|c|c|c|c|c|c|c|}
\hline $\begin{array}{c}\text { Dependent Variable: } \\
\text { De facto Judicial Independence } \\
\text { Independent Variables } \\
\end{array}$ & 1 & 2 & 3 & 4 & 5 & 6 & 7 \\
\hline LAYASSCON & $\begin{array}{l}0.039 \\
(0.47)\end{array}$ & $\begin{array}{c}0.229 * \\
(2.44)\end{array}$ & & & & & \\
\hline LAYPHIS & & & $\begin{array}{c}0.133^{*} \\
(2.14) \\
\end{array}$ & $\begin{array}{c}0.119\left(^{*}\right) \\
(1.89) \\
\end{array}$ & $\begin{array}{c}0.127\left(^{*}\right) \\
(1.83) \\
\end{array}$ & $\begin{array}{c}0.142 * \\
(2.10) \\
\end{array}$ & $\begin{array}{c}0.142 * \\
(2.15) \\
\end{array}$ \\
\hline$E L F$ & $\begin{array}{c}-0.077 \\
(0.57)\end{array}$ & $\begin{array}{l}0.052 \\
(0.49)\end{array}$ & & $\begin{array}{c}-0.147 \\
(1.26)\end{array}$ & $\begin{array}{c}-0.206 \\
(1.37)\end{array}$ & & $\begin{array}{l}-0.141 \\
(1.01)\end{array}$ \\
\hline$E D U$ & & & & & $\begin{array}{c}-0.002 \\
(1.32) \\
\end{array}$ & & $\begin{array}{c}-0.003 \\
(1.64)\end{array}$ \\
\hline$E L F^{*} L P$ & & $\begin{array}{c}-0.618 * * \\
(3.59)\end{array}$ & & & & & \\
\hline COMMONLO & & & & & & $\begin{array}{c}-0.061 \\
(0.50) \\
\end{array}$ & $\begin{array}{c}-0.021 \\
(0.14) \\
\end{array}$ \\
\hline FRENCHLO & & & & & & $\begin{array}{l}0.023 \\
(0.30) \\
\end{array}$ & $\begin{array}{l}0.024 \\
(0.29) \\
\end{array}$ \\
\hline GERMANLO & & & & & & $\begin{array}{c}0.212 * \\
(2.67) \\
\end{array}$ & $\begin{array}{c}0.202 * \\
(2.46) \\
\end{array}$ \\
\hline SOCIALO & & & & & & $\begin{array}{c}-0.011 \\
(0.08)\end{array}$ & $\begin{array}{c}-0.179 \\
(0.84)\end{array}$ \\
\hline Constant & 4.587 & 4.748 & 6.124 & 5.906 & 6.461 & 5.183 & 5.113 \\
\hline Adjusted $\mathrm{R}^{2}$ & 0.415 & 0.479 & 0.398 & 0.518 & 0.442 & 0.421 & 0.504 \\
\hline SER & 0.186 & 0.175 & 0.193 & 0.173 & 0.178 & 0.190 & 0.168 \\
\hline Jarque-Bera Value & 2.143 & 2.113 & 0.833 & 0.855 & 0.540 & 4.924 & 4.223 \\
\hline Observations & 44 & 44 & 55 & 47 & 44 & 55 & 44 \\
\hline \multicolumn{8}{|c|}{$\begin{array}{l}(*), * \text { and } * * \text { show that the estimated parameter is significantly different from zero on the } 10,5 \text {, or } 1 \text { percent level, respectively. } \\
\text { The numbers in parentheses are the absolute values of the estimated t-statistics based on White heteroscedasticity-consistent } \\
\text { standard errors. SER is the standard error of the regression, and J.-B. the value of the Jarque-Bera-test on normality of the } \\
\text { residuals. All regressions include AGE, CHECKS95, and POLIV as standard explanatory variables. "LP" indicates the lay } \\
\text { participation variable that is interacted. }\end{array}$} \\
\hline
\end{tabular}

21 Note that the coefficients of the M-vector variables are not displayed in the table in order to save space. 
they turn out insignificant. The constitutional LP dummies are only significant when interacted with the level of ethno-linguistic fractionalization or education.

When LAYPCON is interacted with education, this variable is statistically significant. Economically, it is negligible: every 10 point increase in education would improve de facto JI by 0.08 (on a scale from 0 to 1 ). This result is not reported in the table in order to safe space. The interaction term between LAYASSCON and ethno-linguistic fractionalization is more significant, both statistically and substantially: Given that lay assessors are constitutionally entrenched, higher levels of ethno-linguistic fractionalization are strongly correlated with lower levels of de facto JI. We interpret this as a confirmation of the conjecture that LP will have unwelcome effects if implemented in an environment characterized by a high level of fractionalization.

Finally, history does seem to matter: countries that have ever had any form of LP (LAYPHIS) can expect to realize higher levels of de facto JI than countries that have not. This result is robust to the inclusion of ethno-linguistic fractionalization, education and legal origins. Note that German legal origin countries have significantly more independent judiciaries than the Scandinavian benchmark group. All other legal origins don't show significant differences to the benchmark.

We move on to the question whether LP is one determinant for differences in the reported level of corruption within the judiciary (results depicted in table 3 ). In our benchmark equation, we use three variables as the M-vector, namely (1) an indicator for procedural formalism (operationalized with regard to a hypothetical case, namely the eviction of a tenant, hence its name "eviction"; Djankov et al. 2003). The conjecture is that higher levels of procedural formalism make the judiciary a more attractive target for corruption. (2) Per capita income (higher levels are conjectured to be correlated with lower levels of judicial corruption) and (3) a dummy for OECD-membership. In an estimation based on 71 countries, these three variables "explain" almost $70 \%$ of the variation in reported levels of corruption within the judiciary (adj. $\left.\mathrm{R}^{2}: 0.6952\right)$. The dependent variable is coded from 1 ("common") to 7 ("never occurs").

Trial by jury does not have any effect on judicial corruption (not reported in table 3). As with regard to de facto judicial independence, a history of LP is one of the few LP variables showing up as significant. The result is robust to the inclusion of ethno-linguistic fractionalization, education and legal origins (column 2 through 4). Regarding legal origins, both French and socialist countries suffer from significantly more corrupt judiciaries than the Scandinavian benchmark countries. Whereas LAYPHIS encompasses all forms of LP, TIMECRIM is restricted to the 
number of years that LP with regard to criminal cases has been (or was) in place. Somewhat unexpectedly, TIMECRIM has a negative coefficient, implying a negative effect on judicial corruption. Although the coefficient needs to be multiplied by the number of years such competence has existed, the substantial effect seems rather limited: the effect of LAYPHIS would only be compensated after it has been in existence for some 180 years. Caution in the interpretation of these results is also in order due to the low number of observations.

Table 3: Lay Participation and Corruption within Judiciary

\begin{tabular}{|c|c|c|c|c|c|c|c|}
\hline $\begin{array}{c}\begin{array}{c}\text { Dependent Variable: } \\
\text { Judicial Corruption }\end{array} \\
\end{array}$ & 1 & 2 & 3 & 4 & 5 & 6 & 7 \\
\hline LAYPHIS & $\begin{array}{c}0.508(*) \\
(1.98)\end{array}$ & $\begin{array}{c}0.529(*) \\
(1.78)\end{array}$ & $\begin{array}{c}0.673^{*} \\
(2.28) \\
\end{array}$ & & & & \\
\hline TIMECRIM & & & & $\begin{array}{c}-0.003\left(^{*}\right) \\
(1.75) \\
\end{array}$ & $\begin{array}{c}-0.003 * \\
(2.30) \\
\end{array}$ & $\begin{array}{c}-0.004(*) \\
(1.84) \\
\end{array}$ & $\begin{array}{c}-0.026^{*} \\
(2.20) \\
\end{array}$ \\
\hline ELF & & $\begin{array}{l}0.094 \\
(0.17) \\
\end{array}$ & $\begin{array}{c}-0.426 \\
(0.74) \\
\end{array}$ & & $\begin{array}{c}-1.048 \\
(1.13) \\
\end{array}$ & $\begin{array}{l}1.208 \\
(1.33) \\
\end{array}$ & $\begin{array}{c}-1.852\left(^{*}\right) \\
(1.75) \\
\end{array}$ \\
\hline$E D U$ & & $\begin{array}{c}0.014\left(^{*}\right) \\
(1.96)\end{array}$ & $\begin{array}{c}0.022^{*} \\
(2.60)\end{array}$ & & $\begin{array}{l}0.008 \\
(0.65)\end{array}$ & $\begin{array}{c}0.024(*) \\
(2.08)\end{array}$ & $\begin{array}{l}0.010 \\
(0.71)\end{array}$ \\
\hline$E D U^{*} L P$ & & & & & & & $\begin{array}{c}0.000(*) \\
(1.94) \\
\end{array}$ \\
\hline COMMONLO & & & $\begin{array}{l}0.062 \\
(0.13) \\
\end{array}$ & & & $\begin{array}{c}-0.068 \\
(0.13) \\
\end{array}$ & $\begin{array}{l}0.587 \\
(0.66) \\
\end{array}$ \\
\hline FRENCHLO & & & $\begin{array}{c}-0.737^{*} \\
(2.23) \\
\end{array}$ & & & $\begin{array}{c}-0.589^{*} \\
(2.29) \\
\end{array}$ & $\begin{array}{c}-0.648^{*} \\
(2.85) \\
\end{array}$ \\
\hline GERMANLO & & & $\begin{array}{l}-0.392 \\
(1.23) \\
\end{array}$ & & & $\begin{array}{l}0.011 \\
(0.03) \\
\end{array}$ & $\begin{array}{l}0.152 \\
(0.37) \\
\end{array}$ \\
\hline SOCIALO & & & $\begin{array}{c}-0.779(*) \\
(1.80)\end{array}$ & & & $\begin{array}{c}-1.196 * * \\
(2.95)\end{array}$ & $\begin{array}{c}-1.150^{* *} \\
(3.03)\end{array}$ \\
\hline Constant & -1.370 & -0.989 & -1.360 & -1.735 & 1.538 & 1.139 & 0.995 \\
\hline Adjusted $\mathrm{R}^{2}$ & 0.738 & 0.765 & 0.788 & 0.740 & 0.779 & 0.810 & 0.835 \\
\hline SER & 0.648 & 0.617 & 0.586 & 0.593 & 0.547 & 0.508 & 0.473 \\
\hline Jarque-Bera Value & 2.428 & 1.737 & 1.924 & 1.792 & 1.119 & 0.456 & 0.236 \\
\hline Observations & 52 & 46 & 46 & 30 & 27 & 27 & 27 \\
\hline \multicolumn{8}{|c|}{$\begin{array}{l}(*), * \text { and } * * \text { show that the estimated parameter is significantly different from zero on the } 10,5 \text {, or } 1 \text { percent level, respectively. } \\
\text { The numbers in parentheses are the absolute values of the estimated t-statistics based on White heteroscedasticity-consistent } \\
\text { standard errors. SER is the standard error of the regression, and J.-B. the value of the Jarque-Bera-test on normality of the } \\
\text { residuals. All regressions include EVICTION, LYP and OECD as standard explanatory variables. "LP" indicates the lay } \\
\text { participation variable that is interacted. }\end{array}$} \\
\hline
\end{tabular}

This concludes our analysis of the effects of LP on the judicial system. If LP has any effects, they seem to be rather weak. Among the weak effects, the one induced by the variable "LAYPHIS" seems to be strongest: it is significant as an 
explanatory variable for both independent variables and seems to be rather robust. We now move on the question whether LP has any effects on broader variables.

We begin by analyzing potential effects on governance indicators. None of the 13 LP variables has a significant effect on either GRAFT or CPI. We hence constrain the discussion of the results to government effectiveness. The benchmark equation follows Persson and Tabellini (2003) and includes the average of political freedom and civil liberties, the "democratic age" of countries, their per capita

Table 4: Lay Participation and Government Effectiveness

\begin{tabular}{|c|c|c|c|c|c|c|c|c|}
\hline $\begin{array}{c}\begin{array}{c}\text { Dependent Variable: } \\
\text { Government Effectiveness }\end{array} \\
\text { Independent Variables }\end{array}$ & 1 & 2 & 3 & 4 & 5 & 6 & 7 & 8 \\
\hline$L A Y P$ & $\begin{array}{l}0.787 \\
(1.66)\end{array}$ & $\begin{array}{c}-1.569 \\
(1.52)\end{array}$ & $\begin{array}{c}-2.781(*) \\
(1.83)\end{array}$ & & & & & \\
\hline JURY & & & & $\begin{array}{c}-2.553 * \\
(2.62)\end{array}$ & & & & \\
\hline LAYASS & & & & & $\begin{array}{l}0.670 \\
(1.54)\end{array}$ & $\begin{array}{r}-1.403 \\
(1.68)\end{array}$ & & \\
\hline JURYCON & & & & & & & $\begin{array}{c}-2.101(*) \\
(1.94)\end{array}$ & \\
\hline LAYASSCON & & & & & & & & $\begin{array}{c}-3.304 * * \\
(3.40)\end{array}$ \\
\hline ELF & $\begin{array}{l}1.056 \\
(0.96)\end{array}$ & $\begin{array}{l}-0.475 \\
(0.88)\end{array}$ & $\begin{array}{l}-0.625 \\
(1.07)\end{array}$ & $\begin{array}{l}0.088 \\
(0.16)\end{array}$ & $\begin{array}{l}0.903 \\
(0.98)\end{array}$ & $\begin{array}{l}-0.457 \\
(0.76)\end{array}$ & $\begin{array}{l}-0.579 \\
(0.81)\end{array}$ & $\begin{array}{l}-1.23 \\
(1.60)\end{array}$ \\
\hline$E D U$ & $\begin{array}{c}-0.015\left(^{*}\right) \\
(1.72)\end{array}$ & $\begin{array}{c}-0.025 * * \\
(2.83) \\
\end{array}$ & $\begin{array}{c}-0.009 \\
(0.91) \\
\end{array}$ & $\begin{array}{c}-0.029 * * \\
(3.51)\end{array}$ & $\begin{array}{c}-0.016\left(^{*}\right) \\
(1.81)\end{array}$ & $\begin{array}{c}-0.024 * \\
(2.63) \\
\end{array}$ & $\begin{array}{c}-0.019(*) \\
(1.73)\end{array}$ & $\begin{array}{c}-0.017 \\
(1.50) \\
\end{array}$ \\
\hline GINI & & & $\begin{array}{c}-0.088^{*} \\
(2.33)\end{array}$ & & & & & $\begin{array}{l}-0.030 \\
(1.11)\end{array}$ \\
\hline$E L F^{*} L P$ & $\begin{array}{c}-1.999(*) \\
(1.69)\end{array}$ & & & & $\begin{array}{c}-1.919\left(^{*}\right) \\
(1.81)\end{array}$ & & & \\
\hline$E D U^{*} L P$ & & $\begin{array}{c}0.021(*) \\
(1.84)\end{array}$ & & $\begin{array}{c}0.028^{*} \\
(2.66)\end{array}$ & & $\begin{array}{c}0.018^{*} \\
(2.09)\end{array}$ & $\begin{array}{c}0.021\left(^{*}\right) \\
(1.90)\end{array}$ & \\
\hline$G I N I * L P$ & & & $\begin{array}{c}0.080^{*} \\
(2.10)\end{array}$ & & & & & $\begin{array}{c}-0.076^{* *} \\
(3.47)\end{array}$ \\
\hline Constant & 9.249 & 8.409 & 17.443 & 7.235 & 8.390 & 7.711 & 5.325 & 6.313 \\
\hline Adjusted $\mathrm{R}^{2}$ & 0.844 & 0.840 & 0.838 & 0.835 & 0.829 & 0.823 & 0.822 & 0.830 \\
\hline SER & 0.800 & 0.810 & 0.819 & 0.856 & 0.845 & 0.858 & 0.893 & 0.857 \\
\hline Jarque-Bera Value & 2.771 & $7.013 * *$ & 8.634 & $6.034 *$ & 1.970 & 7.062 & 8.081 & 2.218 \\
\hline Observations & 56 & 56 & 50 & 52 & 50 & 50 & 47 & 44 \\
\hline $\begin{array}{l}(*), * \text { and } * * \text { show that the estir } \\
\text { numbers in parentheses are the } \\
\text { SER is the standard error of the } \\
\text { GASTIL, AGE, LYP, LPOP, E } \\
\text { "LP" indicates the lay participa }\end{array}$ & $\begin{array}{l}\text { d paramete } \\
\text { olute values } \\
\text { ression, an } \\
\text { TRADE, } \\
\text { variable th }\end{array}$ & $\begin{array}{l}\text { s significar } \\
\text { f the estim } \\
\text { - } \mathrm{B} \text {. the va } \\
\mathrm{CD}, \text { FEDE } \\
\text { is interacte }\end{array}$ & $\begin{array}{l}\text { y different } \\
\text { d t-statistic } \\
\text { of the Jarc } \\
\text { AL, ELF, P }\end{array}$ & $\begin{array}{l}\mathrm{n} \text { zero on } \\
\text { ased on W } \\
\text {-Bera-test } \\
\text { T80, CAT }\end{array}$ & $\begin{array}{l}10,5 \text {, or } 1 \\
\text { heterosce } \\
\text { normality } \\
30, \text { CONFU }\end{array}$ & $\begin{array}{l}\text { cent level } \\
\text { ticity-con } \\
\text { he residua } \\
\text { standard }\end{array}$ & $\begin{array}{l}\text { spectively. } \\
\text { ent standarc } \\
\text { All regressi } \\
\text { lanatory va }\end{array}$ & $\begin{array}{l}\text { rrors. } \\
\text { s include } \\
\text { bles. }\end{array}$ \\
\hline
\end{tabular}


income, the size of the population, education, the sum of exports plus imports as a share of GDP, OECD membership, whether a country is a federal state, the level of ethno-linguistic fractionalization, the percentage of protestants, of catholics and a dummy for societies dominated by Confucian traditions. The benchmark already explains more than 80 percent of the variation in reported levels of government effectiveness (the estimate includes 78 countries, the adj. $R^{2}$ is 0.8295 ).

Concerning the augmentation of the benchmark equation with single variables, only HISJUR - i.e. having a history of trial by jury - shows up as significant. Yet, the number of observations is rather low. For what it is worth, the variable has the "wrong" sign (a history of trial by jury being correlated with lower levels of government effectiveness) and furthermore, the variable is not significant as soon as legal origins are controlled for (not documented in table).

LAYP as such is not significant. The interaction effect of LAYP with ethnolinguistic fractionalization, education, and the distribution of wealth does, however, show some statistical significance. The dependent variable is coded such that lower values stand for higher levels of effectiveness. The unconditional effect of ethno-linguistic fractionalization is as expected: higher values are correlated with higher values of government effectiveness, i.e. lower effectiveness. If ethnolinguistic fractionalization is interacted with Lay Participation, a negative coefficient emerges which overcompensates the unconditional effect. Hence, given that any kind of lay participation exists, higher levels of ethno-linguistic fractionalization are correlated with higher levels of government effectiveness! The other two interaction effects (columns 2 and 3 ) are substantially negligible.

Other cases where the substantial results are marginal at best are documented in columns 4, 6 and 7. The only other noteworthy results of table 4 are in columns 5 and 8: If ethno-linguistic fractionalization is interacted with LAYASS, it leads to higher values of government effectiveness. In column 8 , we observe another unexpected result: given that lay assessors are entrenched in the constitution (LAYASSCON), higher Gini-coefficients improve government effectiveness.

We now move on to the fourth group of dependent variables, namely output per worker and total factor productivity. Drawing on Persson and Tabellini (2003) again, we use an identical $\mathrm{M}$-vector for both dependent variables that consists of whether a state has a federal structure, the absolute latitude of the state, the fraction of the population speaking English as a native language, the fraction of the population speaking any of the major European languages, and the tradeshare predicted on the basis of a simple gravity model only taking into account the 
country's population and geographical factors. This benchmark model "explains" some $58 \%$ of the variation with regard to output per worker.

Table 5: Lay Participation and Output per Worker / Total Factor Productivity

\begin{tabular}{|c|c|c|c|c|c|c|c|c|}
\hline \multirow[b]{2}{*}{ Independent Variables } & \multicolumn{4}{|c|}{$\begin{array}{l}\text { Dependent Variable: } \\
\text { LOGYL } 2000\end{array}$} & \multicolumn{4}{|c|}{$\begin{array}{c}\text { Dependent Variable: } \\
\text { TFP } 2000\end{array}$} \\
\hline & 1 & 2 & 3 & 4 & 5 & 6 & 7 & 8 \\
\hline LAYASSCON & $\begin{array}{l}-0.674^{*} \\
(2.36) \\
\end{array}$ & $\begin{array}{c}-0.616^{* *} \\
(2.97) \\
\end{array}$ & $\begin{array}{c}-0.583 * * \\
(3.18) \\
\end{array}$ & $\begin{array}{c}-0.661 * * \\
(3.09) \\
\end{array}$ & $\begin{array}{c}-0.591 * \\
(2.08) \\
\end{array}$ & $\begin{array}{c}-0.558^{*} \\
(2.34) \\
\end{array}$ & $\begin{array}{c}-0.565^{*} \\
(2.33) \\
\end{array}$ & $\begin{array}{c}-0.676^{* *} \\
(2.93) \\
\end{array}$ \\
\hline$E L F$ & & $\begin{array}{l}-1.130 \\
(2.24)\end{array}$ & $\begin{array}{l}-0.898 \\
(2.24)\end{array}$ & $\begin{array}{c}-0.849(*) \\
(1.99)\end{array}$ & & $\begin{array}{l}-0.639 \\
(1.51)\end{array}$ & $\begin{array}{l}-0.694 \\
(1.65)\end{array}$ & $\begin{array}{l}-0.655 \\
(1.66)\end{array}$ \\
\hline$E D U$ & & & $\begin{array}{c}0.018^{* *} \\
(4.48) \\
\end{array}$ & $\begin{array}{c}0.017 * * \\
(4.01) \\
\end{array}$ & & & $\begin{array}{l}-0.004 \\
(1.22) \\
\end{array}$ & $\begin{array}{l}-0.006 \\
(1.62) \\
\end{array}$ \\
\hline GINI & & & & $\begin{array}{c}-0.023^{*} \\
(2.08)\end{array}$ & & & & $\begin{array}{c}-0.019 * \\
(2.28)\end{array}$ \\
\hline Constant & 7.253 & 7.945 & 6.763 & 7.907 & 7.271 & 7.663 & 7.942 & 8.895 \\
\hline Adjusted $\mathrm{R}^{2}$ & 0.657 & 0.703 & 0.771 & 0.799 & 0.531 & 0.561 & 0.559 & 0.663 \\
\hline SER & 0.575 & 0.535 & 0.470 & 0.448 & 0.436 & 0.422 & 0.423 & 0.382 \\
\hline Jarque-Bera Value & 2.237 & 1.682 & $8.868^{*}$ & 0.301 & 0.275 & 0.093 & 0.138 & 4.354 \\
\hline Observations & 47 & 47 & 47 & 43 & 47 & 47 & 47 & 43 \\
\hline
\end{tabular}

If the benchmark model is augmented with one of the $13 \mathrm{LP}$ variables at a time, none of the variables is robustly significant for explaining differences in output per worker. LAYASSCON (reported in columns 4 and 5 of table 5) and HISCIV are significant as long as no controls are added, but with a negative sign. HISCRIM has a positive sign, is robust to the inclusion of legal origins but there are only 25 observations for that variable.

Results for total factor productivity are pretty similar. Augmenting the benchmark model with one LP variable at a time only leads to significant coefficients in two cases, namely with LAYASSCON and HISCRIM. HISCRIM has a positive effect on total factor productivity. The coefficient is remarkably robust, surviving the inclusion of legal origins as well as a dummy for membership in the Judicial Committee of the Privy Council. We refrain from including the results in table 6 since there are only 25 observations. The other variable that reaches significance (LAYASSCON) is reported in columns 5 through 8 of table 5 . 
Throughout, an entrenchment of lay assessors in the constitution has a negative effect on both output per worker as well as on total factor productivity. In conclusion it seems fair to say that the effects of LP on governance indicators as well as on labor as well as on total factor productivity are modest at most.

So far, our main focus has been on the question whether any kind of LP has systematic effects on the judiciary, the political system or economic variables. A different take of the issue would be to focus more on the differences between jury systems on the one hand and systems drawing on lay assessors on the other. At least some scholars would argue that the first would protect the individual from the state whereas the second was less likely to do so. If any kind of LP was positively correlated with judicial independence, it was rather lay assessors than juries (table 2). No significant differences could be identified with regard to LP and corruption within the judiciary (table 3 ). The picture changes, however, as soon as we turn to government effectiveness (table 4): here, jury systems display a significant effect on government effectiveness (on the 5\% level), whereas lay assessors do not. Finally, table 5 shows that constitutionally entrenched lay assessors ("LAYASSCON") have a negative effect on both output per worker and total factor productivity. If the same models are run with constitutionally entrenched juries (not in the table), this variable never reaches the $10 \%$ significance level. In other words: whereas lay assessors have a negative influence, juries do not.

\section{Conclusions and Outlook}

This is the first paper assessing the effects of lay participation in judicial decisionmaking on a cross-country basis. It is based on a newly assembled data base comprising up to 80 countries. It is shown that, contrary to conventional wisdom, trial by jury and a common law legal tradition are not significantly correlated. Comparing systems relying on trial by jury with those relying on lay assessors, bivariate correlations indicate that countries relying on juries do better with regard to political freedom, civil liberty, freedom of the press and the realized level of democracy. Further, declared interest in politics is generally higher in these countries. On the other hand, people in countries relying on lay assessors display a higher level of general trust which has been shown to be of economic relevance as it facilitates economic exchange.

Some legal philosophers have argued that the effects of lay participation should be more pronounced via a political, rather than a judicial, transmission mechanism. If anything, the results presented here show that the opposite might be closer to the 
truth: lay participation has some positive effects on the judicial system (in terms of higher levels of de facto judicial independence and lower levels of corruption within the judiciary) but the effects on general governance indicators as well as on economic variables appear very uncertain. This implies, however, that a stylized economic argument pointing at the foregone benefits of a constrained division of labor is not corroborated either.

In defense of the legal philosophers, one could add that today's judicial systems are very different from the systems they were describing. On a more general note, it could be remarked that given the few cases dealt with by LP and the few citizens participating as lay persons, it would be presumptuous to expect significant effects on the macro level. Yet, their hypotheses were formulated on the macro level. Future studies might, of course, prefer to choose a more micro level.

A more micro level might also be chosen if one is interested in highlighting the specific differences within jury or lay assessor systems. Not all of them are identical and some important 'within-system variation' might have gone unnoticed in this study. Case-studies might be one way of dealing with this kind of variation.

Many of the hypotheses developed in section 2 of this paper have not been tested here in order to keep the paper reasonably short. It almost suggests itself to test the other hypotheses, too. Of course, there are many aspects not explicitly discussed here that would also deserve to be tested empirically. These include possible effects of jury size (e.g. on the perceived legitimacy of the judiciary as a whole), the modus of appointing lay judges and their socio-economic composition, the decision-rules used in lay participation, the likelihood of ever serving in a lay panel and so forth. 
Thank you!

The creation of the dataset on which this paper is based would have been impossible if the experts named here had not generously helped with their time and expertise. A heartfelt thanks to all of them again!

Orlando Pulvirenti, Professor of Human Rights and Constitutional Law, School of Law, National University of Buenos Aires (UBA), (Argentina); Georg Stawa, judge assigned to the Ministry of Justice, Vienna (Austria); Professor Boudewyn Bouckart, CASLE, Ghent (Belgium); The Danish Ministry of Justice (Denmark); Solomon Areda, Judge at Federal High Court of Ethiopia (Ethiopia); Abg. César Vaca Sánchez, Coronel y Pérez, Abogados, Guayaquil (Ecuador); Age Värv, LL.M, Adviser, Courts Administration

Division, Ministry of Justice of Estonia (Estonia); Stéphane Cottin, Conseil constitutionnel (France); Mariam Hamidu, Assistant State Attorney, Ministry of Justic and Attorney General's Department (Ghana); Organismo Judicial Licda. Lizett Najera Flores de Flores; Licda. Enma Graciela Salazar Castillo (Guatemala); Department of Justice, Equality and Law Refom; Bar Council of Ireland (Ireland); Oren Gazal-Ayal, University of Haifa, Faculty of Law (Israel); Giovanni Cordini, Full Professor of Public Comparative Law, University of Pavia (Italy); Badri and Salim El Meouchi Law Firm, Chadia El Meouchi, Jihad Rizkallah and Samia El Meouchi (Lebanon); Ministère de la Justice (Madagascar); Pacharo Kayira, Senior Assistant Chief State Advocate in the Ministry of Justice in the Directorate of Public Prosecutions (Malawi); Attorney General's Office (Mauritius); Slaven Scepanovic, lawyer (Montenegro); Dr. Uju Agomoh, PRAWA (Nigeria); Dr. Khalil Ahmad (Pakistan); Carlos Ernesto González Ramírez (Panama); Centro Paraguayo para la Promoción de la Libertad Económica y de la Justicia Social (CEPPRO) (Paraguay); José Luis Sardón, Director Ejecutivo de la Sociedad de Economía y Derecho UPC (Peru); Stephen C. Thaman, Professor, Saint Louis University School of Law (Russia); Bernhard Seliger (South Korea); Prof. Dr. Juan-Luis Gómez Colomer and Dr. María-Angeles Pérez Cebadera, University Jaume I Castellón (Spain); Juliet Kaira Chibuta, Southern African Legal Assistance Network (Zambia). 


\section{References}

Benz, M. and A. Stutzer (2004); Are voters better informed when they have a larger say in politics? - Evidence for the European Union and Switzerland, Public Choice 119:31-59.

Berggren, N., M. Elinder and H. Jordahl (2008). Trust and growth: a shaky relationship. Forthcoming in: Empirical Economics.

Blackstone, W. (1791/1966); Commentaries on the Laws of England, London: Clarendon.

Djankov, S., R. La Porta, F. Lopez-de-Silanes and A. Shleifer (2003); Courts: The Lex Mundi Project, Quarterly Journal of Economics, 118(2):453-517.

Duff, P. (2000); The Scottish Criminal Jury: A Very Peculiar Institution, in: Vidmar, N. (ed.): World Jury Systems, Oxford: Oxford University Press, 249-82.

Feld, L. and S. Voigt (2003); Economic Growth and Judicial Independence: Cross Country Evidence Using a New Set of Indicators, European Journal of Political Economy 19(3).497-527.

Feld, L. and S. Voigt (2006); Making Judges Independent - Some Proposals Regarding the Judiciary, in: R. Congleton and B. Swedenborg (eds.): Democratic Constitutional Design and Public Policy - Analysis and Evidence, Cambridge: MIT Press 251-288.

Frey, B.S., M. Benz, A. Stutzer (2004). Introducing Procedural Utility: Not Only What, but Also How Matters, Journal of Institutional and Theoretical Economics, 160(3):377-401.

Hegel, G.W.F. (1821); Grundlinien der Philosophie des Rechts, Berlin: Nicolaische Buchhandlung. The 1897 Dyde translation with some modifications is used for the Preface \& the Introduction and the Knox translation for the remainder of Hegel's Philosophy of Right, which was first published in 1821, and is an extended version of Objective Spirit from the Encyclopedia, and a continuation of Hegel's early writings on political economy.

Jeary, J.H. (1960/61); Trial by Jury and Trial with the Aid of Assessors in the Superior Courts of British African Territories: I and II, Journal of African Law, 4(3):133-46 and 5(1): 36-47.

Kirchgässner, G. and Pommerehne, W. (1993); Low-cost decisions as a challenge to public choice, Public Choice, 77:107-15.

Kiss, L. (2000); Reviving the Criminal Jury in Japan, in: Vidmar, N. (ed.): World Jury Systems, Oxford: Oxford University Press, 353-80.

Kutnjak Ivkovic, S. (1999); Lay Participation in Criminal Trials - The Case of Croatia, Lanham et al.: Austin \& Winfield.

La Porta, R., F. Lopez-de-Silanes, A. Shleifer and R. Vishny (1999); The Quality of Government, The Journal of Law, Economics \& Organistaion, Vol. 15,. No. 1: 222-279.

Mauro, Paolo (1995); Corruption and Growth, Quarterly Journal of Economics, 110:681-712

Montesquieu (1748/1965); Vom Geist der Gesetze, Stuttgart: Reclam.

Munday, R. (1993); Jury trial, continental style, Legal Studies 13:204-24.

Persson, T. and G. Tabellini (2003), The Economic Effects of Constitutions: What Do the Data Say?, Cambridge: MIT Press.

Smith, A. (1992); Lectures on Jurisprudence, ed. by R. Meek, D. Raphael and P. Stein, Indianapolis: Liberty Fund. 
Thaman, St. (2000); Europe's New Jury Systems: The Cases of Spain and Russia, in: Vidmar, N. (ed.): World Jury Systems, Oxford: Oxford University Press, 319-51.

Tocqueville, A. de (1835/1956); Democracy in America, New York: Mentor.

Voigt, S. (2008); "The Economic Effects of Judicial Accountability - Cross-Country Evidence",

European Journal of Law and Economics 25(2):95-123.

\section{Appendix 1: Description and Descriptive Statistics of LAY PARTICIPATION variables}

\begin{tabular}{|c|c|c|c|c|c|c|}
\hline Abbreviation & Description & $\begin{array}{l}\text { Number of } \\
\text { observations }\end{array}$ & Minimum & Maximum & Mean & $\begin{array}{l}\text { Standard } \\
\text { Deviation }\end{array}$ \\
\hline LAYP & $\begin{array}{l}\text { Dummy coded } 1 \text { if state } \\
\text { has any kind of lay } \\
\text { participation }\end{array}$ & 80 & 0 & 1 & 0.663 & 0.479 \\
\hline JURY & $\begin{array}{l}\text { Dummy coded } 1 \text { if state } \\
\text { has trial by jury }\end{array}$ & 72 & 0 & 1 & 0.375 & 0.488 \\
\hline LAYASS & $\begin{array}{l}\text { Dummy coded } 1 \text { if state } \\
\text { has lay assessors }\end{array}$ & 73 & 0 & 1 & 0.493 & 0.503 \\
\hline LAYPCON & $\begin{array}{l}\text { Dummy coded } 1 \text { if any } \\
\text { kind of lay participation } \\
\text { mentioned in constitution }\end{array}$ & 69 & 0 & 1 & 0.275 & 0.450 \\
\hline JURYCON & $\begin{array}{l}\text { Dummy coded } 1 \text { trial by } \\
\text { jury mentioned in } \\
\text { constitution }\end{array}$ & 69 & 0 & 1 & 0.275 & 0.450 \\
\hline LAYASSCON & $\begin{array}{l}\text { Dummy coded } 1 \text { if lay } \\
\text { assessors mentioned in } \\
\text { constitution }\end{array}$ & 71 & 0 & 1 & 0.155 & 0.364 \\
\hline LAYPHIS & $\begin{array}{l}\text { Dummy coded } 1 \text { if state } \\
\text { has had any kind of lay } \\
\text { participation in its history }\end{array}$ & 73 & 0 & 1 & 0.767 & 0.426 \\
\hline HISJUR & $\begin{array}{l}\text { Dummy coded } 1 \text { if state } \\
\text { has had trial by jury at } \\
\text { any time. }\end{array}$ & 27 & 0 & 1 & 0.667 & 0.480 \\
\hline HISLAY & $\begin{array}{l}\text { Dummy coded } 1 \text { if state } \\
\text { has had lay assessors at } \\
\text { any time }\end{array}$ & 37 & 0 & 1 & 0.730 & 0.450 \\
\hline HISCRIM & $\begin{array}{l}\text { Dummy coded } 1 \text { if } \\
\text { competence was restricted } \\
\text { to criminal cases }\end{array}$ & 36 & 0 & 1 & 0.500 & 0.507 \\
\hline HISCIV & $\begin{array}{l}\text { Dummy coded } 1 \text { if } \\
\text { competence included civil } \\
\text { cases }\end{array}$ & 35 & 0 & 1 & 0.829 & 0.382 \\
\hline TIMECRIM & $\begin{array}{l}\text { Number of years that lay } \\
\text { participation has been } \\
\text { used }\end{array}$ & 41 & 4 & 266 & 81.659 & 68.862 \\
\hline WEIGHTIME & $\begin{array}{l}\text { Number of years that lay } \\
\text { participation has been } \\
\text { used; if not currently in } \\
\text { use; the number is divided } \\
\text { by } 2 \text {. }\end{array}$ & 41 & 2 & 266 & 74.061 & 73.053 \\
\hline
\end{tabular}




\section{Appendix 2: List of countries including some of their central codings}

Countries with JURIES

\begin{tabular}{|l|c|c|c|c|c|}
\hline & Country & $\begin{array}{l}\text { Constitutionally } \\
\text { entrenched? }\end{array}$ & TIMECRIM & WEIGHTIME & Legal Origin \\
\hline 1 & Algeria & 0 & 34 & 34 & FR \\
\hline 2 & Australia & 1 & $\mathrm{Na}$ & & COM \\
\hline 3 & Austria & 1 & 152 & 152 & GER \\
\hline 4 & Belgium & 1 & 193 & 193 & FR \\
\hline 5 & Brazil & 1 & 178 & 178 & FR \\
\hline 6 & Canada & 1 & 199 & 199 & COM \\
\hline 7 & Denmark & 1 & 84 & 84 & SCA \\
\hline 8 & Finland & 0 & 266 & 266 & SCA \\
\hline 9 & France & 0 & 209 & 209 & FR \\
\hline 10 & Ghana & 1 & 40 & 40 & COM \\
\hline 11 & Greece & 1 & 166 & 166 & FR \\
\hline 12 & Ireland & 1 & $\mathrm{Na}$ & $\mathrm{Na}$ & COM \\
\hline 13 & Madagascar & & 40 & 40 & FR \\
\hline 14 & Malawi & 0 & $\mathrm{Na}$ & $\mathrm{Na}$ & COM \\
\hline 15 & Mauritius & 0 & $\mathrm{Na}$ & $\mathrm{Na}$ & FR \\
\hline 16 & Mexico & 1 & 180 & 180 & FR \\
\hline 17 & New Zealand & & $\mathrm{Na}$ & $\mathrm{Na}$ & COM \\
\hline 18 & Norway & 0 & 113 & 113 & SCA \\
\hline 19 & Panama & 1 & $\mathrm{Na}$ & $\mathrm{Na}$ & FR \\
\hline 20 & Russia & 1 & 7 & 7 & SOC \\
\hline 21 & Senegal & 0 & 40 & 40 & FR \\
\hline 22 & Spain & 1 & 48 & 240 & FR \\
\hline 23 & Sri Lanka & & $\mathrm{Na}$ & $\mathrm{Na}$ & COM \\
\hline 24 & Sweden & 1 & $\mathrm{Na}$ & $\mathrm{Na}$ & SCA \\
\hline 25 & Ukraine & 1 & $\mathrm{Na}$ & $\mathrm{Na}$ & SOC \\
\hline 26 & U. K. & $\mathrm{Na}$ & $\mathrm{Na}$ & $\mathrm{Na}$ & COM \\
\hline 27 & United States & 1 & $\mathrm{Na}$ & $\mathrm{Na}$ & COM \\
\hline
\end{tabular}

Countries with LAY ASSESSORS

\begin{tabular}{|l|c|c|c|c|c|}
\hline & Country & $\begin{array}{l}\text { Constitutionally } \\
\text { entrenched? }\end{array}$ & TIMECRIM & WEIGHTIME & $\begin{array}{l}\text { Legal } \\
\text { Origin }\end{array}$ \\
\hline 1 & Algeria & 0 & 34 & 34 & FR \\
\hline 2 & Australia & 0 & $\mathrm{Na}$ & $\mathrm{Na}$ & COM \\
\hline 3 & Austria & 1 & 152 & 152 & GER \\
\hline 4 & Belgium & 0 & 193 & 193 & FR \\
\hline 5 & Botswana & 0 & $\mathrm{Na}$ & $\mathrm{Na}$ & COM \\
\hline 6 & Bulgaria & 0 & 48 & 48 & SOC \\
\hline 7 & Burkina Faso & 0 & 32 & 32 & FR \\
\hline 8 & Czech Republic & 1 & 32 & 16 & SOC \\
\hline 9 & Denmark & 1 & 84 & 84 & SCA \\
\hline 10 & Estonia & 0 & $\mathrm{Na}$ & $\mathrm{Na}$ & SOC \\
\hline 11 & France & 0 & 209 & 209 & FR \\
\hline 12 & Germany & & $\mathrm{Na}$ & $\mathrm{Na}$ & GER \\
\hline 13 & Ghana & 1 & 40 & 40 & COM \\
\hline 14 & Guatemala & 0 & 8 & 8 & FR \\
\hline 15 & Hungary & 1 & 58 & 29 & SOC \\
\hline 16 & Italy & 0 & 141 & 141 & FR \\
\hline 17 & Latvia & 0 & $\mathrm{Na}$ & $\mathrm{Na}$ & SOC \\
\hline
\end{tabular}




\begin{tabular}{|l|c|c|c|c|c|}
\hline 18 & Lebanon & 0 & $\mathrm{Na}$ & $\mathrm{Na}$ & FR \\
\hline 19 & Madagascar & & 40 & 40 & FR \\
\hline 20 & Malaysia & 0 & $\mathrm{Na}$ & $\mathrm{Na}$ & COM \\
\hline 21 & Mauritius & 0 & $\mathrm{Na}$ & $\mathrm{Na}$ & FR \\
\hline 22 & Norway & 0 & 113 & 113 & SCA \\
\hline 23 & Philippines & 0 & 40 & 40 & FR \\
\hline 24 & Poland & & $\mathrm{Na}$ & $\mathrm{Na}$ & SOC \\
\hline 25 & Senegal & 0 & 40 & 40 & FR \\
\hline 26 & Slovakia & 1 & $\mathrm{Na}$ & $\mathrm{Na}$ & SOC \\
\hline 27 & Slovenia & 1 & 106 & 106 & SOC \\
\hline 28 & South Africa & & $\mathrm{Na}$ & $\mathrm{Na}$ & COM \\
\hline 29 & Swaziland & 1 & 46 & 46 & COM \\
\hline 30 & Sweden & 0 & $\mathrm{Na}$ & $\mathrm{Na}$ & SCA \\
\hline 31 & Switzerland & 0 & 197 & 197 & GER \\
\hline 32 & Turkey & 0 & $\mathrm{Na}$ & $\mathrm{Na}$ & FR \\
\hline 33 & Ukraine & 1 & $\mathrm{Na}$ & $\mathrm{Na}$ & SOC \\
\hline 34 & Venezuela, rp & 0 & $\mathrm{Na}$ & $\mathrm{Na}$ & FR \\
\hline 35 & Vietnam & 1 & $\mathrm{Na}$ & $\mathrm{Na}$ & SOC \\
\hline
\end{tabular}

Countries with JURIES and LAY ASSESSORS

\begin{tabular}{|l|c|}
\hline & Country \\
\hline 1 & Algeria \\
\hline 2 & Australia \\
\hline 3 & Austria \\
\hline 4 & Belgium \\
\hline 5 & Denmark \\
\hline 6 & France \\
\hline 7 & Ghana \\
\hline 8 & Madagascar \\
\hline 9 & Mauritius \\
\hline 10 & Norway \\
\hline 11 & Senegal \\
\hline 12 & Sweden \\
\hline 13 & Ukraine \\
\hline
\end{tabular}

Countries without any lay participation (including justices of the peace and lay magistrates)

\begin{tabular}{|l|c|c|c|c|c|}
\hline & Country & $\begin{array}{l}\text { Constitutionally } \\
\text { entrenched? }\end{array}$ & TIMECRIM & WEIGHTIME & Legal Origin \\
\hline 1 & Albania & 0 & 46 & 23 & SOC \\
\hline 2 & Argentina & 0 & $\mathrm{Na}$ & $\mathrm{Na}$ & $\mathrm{FR}$ \\
\hline 3 & Armenia & 0 & 37 & 18.5 & SOC \\
\hline 4 & Azerbaijan & 0 & $\mathrm{Na}$ & $\mathrm{Na}$ & SOC \\
\hline 5 & Bangladesh & 0 & $\mathrm{na}$ & $\mathrm{Na}$ & $\mathrm{COM}$ \\
\hline 6 & Cambodia & 0 & 13 & 6.5 & FR \\
\hline 7 & Chile & 0 & 104 & 52 & FR \\
\hline 8 & Costa Rica & 0 & 30 & 15 & FR \\
\hline 9 & Cyprus & 0 & $\mathrm{Na}$ & $\mathrm{Na}$ & COM \\
\hline 10 & Ecuador & 0 & $\mathrm{Na}$ & $\mathrm{Na}$ & FR \\
\hline 11 & Egypt, Arab Rep. of & 0 & $\mathrm{Na}$ & $\mathrm{Na}$ & FR \\
\hline 12 & Iceland & 0 & $\mathrm{na}$ & $\mathrm{Na}$ & SCA \\
\hline 13 & India & 0 & $\mathrm{Na}$ & $\mathrm{Na}$ & COM \\
\hline 14 & Indonesia & 0 & $\mathrm{Na}$ & $\mathrm{Na}$ & FR \\
\hline
\end{tabular}




\begin{tabular}{|l|c|c|c|c|c|}
\hline 15 & Israel & 0 & $\mathrm{Na}$ & $\mathrm{Na}$ & COM \\
\hline 16 & Kazakhstan & 0 & $\mathrm{Na}$ & $\mathrm{Na}$ & SOC \\
\hline 17 & Korea (South Korea) & 0 & $\mathrm{Na}$ & $\mathrm{Na}$ & GER \\
\hline 18 & Kyrgyz Republic & 0 & 40 & 20 & SOC \\
\hline 19 & Lithuania & 0 & 52 & 26 & SOC \\
\hline 20 & Moldova & 0 & $\mathrm{Na}$ & $\mathrm{Na}$ & SOC \\
\hline 21 & Netherlands & 0 & $\mathrm{Na}$ & $\mathrm{Na}$ & $\mathrm{FR}$ \\
\hline 22 & Nigeria & 0 & $\mathrm{Na}$ & $\mathrm{Na}$ & $\mathrm{COM}$ \\
\hline 23 & Pakistan & 0 & 102 & 102 & COM \\
\hline 24 & Paraguay & 0 & 70 & 35 & $\mathrm{FR}$ \\
\hline 25 & Peru & 0 & $\mathrm{Na}$ & $\mathrm{Na}$ & $\mathrm{FR}$ \\
\hline 26 & Singapore & 0 & $\mathrm{Na}$ & $\mathrm{Na}$ & COM \\
\hline 27 & Uruguay & 0 & 4 & 2 & FR \\
\hline
\end{tabular}

\section{Appendix 3: List of Variables}

List of Variables (definitions and sources)

AGE:

Age of democracy defined as AGE $=(2000-$ DEM_AGE $) / 200$, with values varying between 0 und 1 ; source: Persson and Tabellini (2003).

\section{CATHO80:}

Percentage of a country's population belonging to the Roman Catholic religion in 1980 (younger states are counted based on their average from 1990 to 1995); source: La Porta (1999) and CIA (2005) for Lithuania, Nauru, Marshall Islands and San Marino.

\section{CHECKS95:}

Number of the factual vetoplayers in 1995; source: Beck et al. (2000)

COL_UK:

Dummy variable, equal to 1 if the country is a former U.K. colony, 0 otherwise, source: CIA (2005).

\section{COMMONLO:}

Dummy variable, equal to 1 if the country belongs to the common law legal origin, 0 otherwise; source: Persson and Tabellini (2003) and CIA.

\section{CONFILEG:}

Confidence in the Legal System: Sum of "complete confidence" and "a great deal of competence" according to ISSP survey 1998.

\section{CONFU:}

Dummy variable fort he religious tradition in a country, equal to 1 if the majority of the country's population is Confucian/Buddhist/Zen, 0 otherwise; source: CIA (2000).

\section{CPI9804:}

Corruption Perception Index measuring perceptions of abuse of power by public officials. Average over 1998 - 2004. Index values between 0 and 10, lower values meaning lower levels of corruption (recoded from the original version); source: Transparency International and Internet Center for Corruption Research (http://www.icgg.org/).

\section{CRIME:}

Total recorded crime per 100000 population; source: UN Survey on Crime Trends and the Operations of Criminal Justice Systems, data for 1994 or closest year available.

\section{DE FACTO JUDICIAL INDEPENDENCE}

Average of up to 9 variables on a scale from 0 (dependent) to 1 (completely independent); source: Feld and Voigt (2006)

\section{EDU:}

Total enrollment in primary and secondary education as a percentage of the relevant age group in the country's population; source: UNESCO (2006): Education statistics.

\section{ELF:}

Index of ethnolinguistic fractionalization, ranging from 0 (homogeneous) to 1 (strongly fractionalized) averaging five 
sources; source: La Porta (1999).

\section{ENGFRAC:}

Fraction of a country's population that speaks English as a native language; source: Hall \& Jones (1999).

\section{EVICTION:}

Procedural formalism regarding a stylized case concerned with the eviction of a tenant; $0=$ very simple and $100=$ highly complex; source: Djankov et al. 2003.

\section{EURFRAC:}

Fraction of a country's population that speaks one of the major languages of Western Europe: English, French, German, Portuguese, or Spanisch; source: Hall \& Jones (1999).

\section{FEDERAL:}

Dummy variable equal to 1 if a country has a federal political structure, 0 otherwise; source: Forum of Federations (2002): List of Federal Countries.

\section{FRANKROM:}

Natural $\log$ of tradeshare forecasted by Frankel and Romer's gravity model of international trade which takes both a country's population and its geographical location into account; source: Hall \& Jones (1999).

\section{FRENCHLO:}

Dummy variable, equal to 1 if the country belongs to the French civil law legal origin, 0 otherweise; source: Persson and Tabellini (2003) and CIA.

\section{GASTIL:}

Average of indexes for civil liberties and political rights, each index is measured on a 1-to-7 scale with 1 representing the highest dgree of freedom. Countries whose averages are between 1 and 2.5 are called "free", those between 3 and 5.5 "partially free" and those between 5.5 and 7 as "not free"; source: Freedom House (2005).

\section{GERMANLO:}

Dummy variable, equal to 1 if the country belongs to the German civil law legal origin, 0 otherwise; source: Persson and Tabellini (2003) and CIA.

\section{GOVEF9604:}

Government effectiveness according to Kaufmann; average values for the years 1996, 1998 and 2000; source: Kaufmann, D., Worldbank (2005): Governance Indicators: 1996-2004.

\section{GRAFT:}

Graft according to the Governance Indicators of the World Bank focusing on perceptions of corruption. Values between 0 and 10, where lower values signal higher effectiveness; source: Kaufmann et al. (1999).

\section{GRAFT9604:}

Graft according to the Governance Indicators of the World Bank; average values for 1996, 1998 and 2000; source: Kaufmann, D., Worldbank (2005): Governance Indicators: 1996-2004.

\section{JUDICIAL CORRUPTION:}

Irregular payments in judicial decisions from 1 ("very common") to 7 ("never occurs"); source: World Economic Forum, Global Competitiveness Report 2004.

\section{LAT01:}

Rescaled variable for latitude, defined as the absolute value of LATITUDE divided by 90 and taking on values between 0 and 1; source: CIA (2005).

\section{LEGAL ORIGINS:}

Dummy variables for COMMON LAW, FRENCH, GERMAN, SCANDINAVIAN and SOCIALIST legal origin; source: La Porta et al. 1998, CIA World Book of Facts.

\section{LOGA 2000:}

Natural logarithm of total factor productivity, own calculation for 2000 based on Hall \& Jones (1999).

\section{LOGYL 2000:}

Natural logarithm of output per worker, own calculation for 2000 based on Hall \& Jones (1999).

\section{LPOP:}

Natural logarithm of total population (in millions); sources: Penn World Tables, Center for International Comparisons at 
the University of Pennsylvania/ CICUP (2006) and CIA (2005).

LYP:

Natural logarithm of real GDP per capita in constant dollars (chain index) expressed in international prices, base year 1985; average for the years 1990 - 1999; source: Column RGDPCH Penn World Tables, Center for International Comparisons at the University of Pennsylvania/ CICUP (2006).

OECD:

Dummy variable, equal to 1 for all countries that were members of the OECD; source: OECD (2006).

PDI:

Power Distance Indicator;

\section{POLCLOSE:}

Variable 217 of the 1999 wave of the World Values Survey indicating how closely the surveyed person was following politics; source: World Values Survey.

\section{POLINTEREST:}

Variable 133 of the 1999 wave of the World Values Survey indicating how interested the surveyed person was in politics, source: World Values Survey.

\section{POLIV:}

Factually realized level of democracy with $-10=$ "perfect" autocracy and $10=$ perfect democracy; source: Polity IV Dataset

\section{PRES:}

Dummy variable for government forms, equal to 1 in presidential regimes, 0 otherwise. Only regimes in which the confidence of the assembly is not necessary for the executive to stay in power (even if an elected president is not chief executive, or if there is no elected president) are included among presidential regimes Most semipresidential and premierpresidential systems are classified as parliamentary source: constitutions and electoral laws.

\section{PRESSFREE:}

Freedom of the Press from $0=$ completely free to $100=$ unfree, source: Freedom House

\section{PROT80:}

Percentage of the population in a country professing the Protestant religion in 1980 (younger states are counted based on their average from 1990 to 1995); source: La Porta (1999) and CIA (2005) for Lithuania, Nauru, Marshall Islands und San Marino.

\section{SOCIALO:}

Dummy variable, equal to 1 if the country belongs to the Socialist law legal origin, 0 otherwise; source: Persson and Tabellini (2003) and CIA.

\section{TRADE:}

Sum of exports plus imports of goods and services measured as a share of GDP; source: Worldbank (2005). 


\section{CESifo Working Paper Series}

for full list see www.cesifo-group.org/wp

(address: Poschingerstr. 5, 81679 Munich, Germany, office@cesifo.de)

2301 Harald Badinger and Peter Egger, GM Estimation of Higher Order Spatial Autoregressive Processes in Panel Data Error Component Models, May 2008

2302 Jan K. Brueckner, Slot-Based Approaches to Airport Congestion Management, May 2008

2303 Sören Blomquist, Vidar Christiansen and Luca Micheletto, Public Provision of Private Goods and Nondistortionary Marginal Tax Rates, May 2008

2304 Dan Anderberg and Alessandro Balestrino, The Political Economy of Post-Compulsory Education Policy with Endogenous Credit Constraints, May 2008

2305 Tomer Blumkin, Yoram Margalioth and Efraim Sadka, The Role of Stigma in the Design of Welfare Programs, May 2008

2306 Vesa Kanniainen and Paolo M. Panteghini, Tax Neutrality: Illusion or Reality? The Case of Entrepreneurship, May 2008

2307 Thomas Dohmen, Armin Falk, David Huffman and Uwe Sunde, The Intergenerational Transmission of Risk and Trust Attitudes, May 2008

2308 Guglielmo Maria Caporale and Mario Cerrato, Using Chebyshev Polynomials to Approximate Partial Differential Equations, May 2008

2309 Peter Egger and Doina Maria Radulescu, Labour Taxation and Foreign Direct Investment, May 2008

2310 Laurent Linnemer, Dissipative Advertising Signals Quality even without Repeat Purchases, May 2008

2311 Jordi Jofre-Monseny and Albert Solé-Ollé, Which Communities should be afraid of Mobility? The Effects of Agglomeration Economies on the Sensitivity of Firm Location to Local Taxes, May 2008

2312 Andreas Haufler and Ferdinand Mittermaier, Unionisation Triggers Tax Incentives to Attract Foreign Direct Investment, May 2008

2313 Ronel Elul and Piero Gottardi, Bankruptcy: Is it enough to Forgive or must we also Forget?, May 2008

2314 Andreas Irmen and Johanna Kuehnel, Productive Government Expenditure and Economic Growth, May 2008

2315 Beate Henschel, Carsten Pohl and Marcel Thum, Demographic Change and Regional Labour Markets: The Case of Eastern Germany, May 2008 
2316 Gabriel Felbermayr, Wido Geis and Wilhelm Kohler, Restrictive Immigration Policy in Germany: Pains and Gains Foregone?, May 2008

2317 Michael Hofmann, Gerhard Kempkes and Helmut Seitz, Demographic Change and Public Sector Budgets in a Federal System, May 2008

2318 Paul De Grauwe, Macroeconomic Modeling when Agents are Imperfectly Informed, June 2008

2319 Johann K. Brunner and Susanne Pech, Optimum Taxation of Inheritances, June 2008

2320 Thomas Eichner and Marco Runkel, Corporate Income Taxation of Multinationals in a General Equilibrium Model, June 2008

2321 Rainald Borck and Matthias Wrede, Subsidies for Intracity and Intercity Commuting, June 2008

2322 Patricia Apps and Ray Rees, Testing the Pareto Efficiency of Household Resource Allocations, June 2008

2323 Amihai Glazer, Vesa Kanniainen and Panu Poutvaara, Firms' Ethics, Consumer Boycotts, and Signalling, June 2008

2324 Claudia M. Buch, Jörg Döpke and Kerstin Stahn, Great Moderation at the Firm Level? Unconditional vs. Conditional Output Volatility, June 2008

2325 Helmuth Cremer, Philippe De Donder, Dario Maldonado and Pierre Pestieau, Forced Saving, Redistribution and Nonlinear Social Security Schemes, June 2008

2326 M. Hashem Pesaran and Paolo Zaffaroni, Optimal Asset Allocation with Factor Models for Large Portfolios, June 2008

2327 Harald Badinger and Peter Egger, Horizontal versus Vertical Interdependence in Multinational Activity, June 2008

2328 Jan K. Brueckner and Harris Selod, A Theory of Urban Squatting and Land-Tenure Formalization in Developing Countries, June 2008

2329 Paolo M. Panteghini, Corporate Debt, Hybrid Securities and the Effective Tax Rate, June 2008

2330 Guglielmo Maria Caporale, Juncal Cuñado and Luis A. Gil-Alana, Modelling Long-Run Trends and Cycles in Financial Time Series Data, June 2008

2331 Avi Ben-Bassat and Momi Dahan, Social Identity and Voter Turnout, June 2008

2332 Martin R. West and Ludger Wößmann, "Every Catholic Child in a Catholic School”: Historical Resistance to State Schooling, Contemporary Private Competition, and Student Achievement across Countries, June 2008 
2333 Erkki Koskela and Panu Poutvaara, Outsourcing and Labor Taxation in Dual Labor Markets, June 2008

2334 Philippe Choné and Laurent Linnemer, Optimal Litigation Strategies with Signaling and Screening, June 2008

2335 Albert Solé-Ollé and Pilar Sorribas-Navarro, Does Partisan Alignment Affect the Electoral Reward of Intergovernmental Transfers?, June 2008

2336 Antonio Cabrales and Piero Gottardi, Markets for Information: Of Inefficient Firewalls and Efficient Monopolies, June 2008

2337 Sumon Majumdar and Sharun W. Mukand, The Leader as Catalyst - on Leadership and the Mechanics of Institutional Change, June 2008

2338 Ulrich Hange, Tax Competition, Elastic Labor Supply, and Growth, June 2008

2339 Guy Laroque and Bernard Salanié, Does Fertility Respond to Financial Incentives?, June 2008

2340 Adriano Paggiaro, Enrico Rettore and Ugo Trivellato, The Effect of Extending the Duration of Eligibility in an Italian Labour Market Programme for Dismissed Workers, June 2008

2341 Helmut Seitz, Minimum Standards, Fixed Costs and Taxing Autonomy of Subnational Governments, June 2008

2342 Robert S. Chirinko, Leo de Haan and Elmer Sterken, Asset Price Shocks, Real Expenditures, and Financial Structure: A Multi-Country Analysis, July 2008

2343 Wolfgang Leininger, Evolutionarily Stable Preferences in Contests, July 2008

2344 Hartmut Egger and Udo Kreickemeier, Fairness, Trade, and Inequality, July 2008

2345 Ngo Van Long and Bodhisattva Sengupta, Yardstick Competition, Corruption, and Electoral Incentives, July 2008

2346 Florian Baumann, Employment Protection: The Case of Limited Enforceability, July 2008

2347 Alessandro Balestrino, Cinzia Ciardi and Claudio Mammini, On the Causes and Consequences of Divorce, July 2008

2348 Dirk Schindler and Benjamin Weigert, Insuring Educational Risk: Opportunities versus Income, July 2008

2349 Lammertjan Dam and Ben J. Heijdra, The Environmental and Macroeconomic Effects of Socially Responsible Investment, July 2008 
2350 Avner Greif, Contract Enforcement and Institutions among the Maghribi Traders: Refuting Edwards and Ogilvie, July 2008

2351 Helmuth Cremer, Philippe De Donder, Dario Maldonado and Pierre Pestieau, Habit Formation and Labor Supply, July 2008

2352 Francesco Menoncin and Paolo M. Panteghini, The Johansson-Samuelson Theorem in General Equilibrium: A Rebuttal, July 2008

2353 Michael Kaganovich and Itzhak Zilcha, Alternative Social Security Systems and Growth, July 2008

2354 Keith Blackburn, Kyriakos C. Neanidis and M. Emranul Haque, Corruption, Seigniorage and Growth: Theory and Evidence, July 2008

2355 Edward Castronova, A Test of the Law of Demand in a Virtual World: Exploring the Petri Dish Approach to Social Science, July 2008

2356 Harald Badinger and Peter Egger, GM Estimation of Higher-Order Spatial Autoregressive Processes in Cross-Section Models with Heteroskedastic Disturbances, July 2008

2357 Wolfgang Buchholz and Jan Schumacher, Discounting the Long-Distant Future: A Simple Explanation for the Weitzman-Gollier-Puzzle, July 2008

2358 Luca Anderlini, Leonardo Felli and Alessandro Riboni, Statute Law or Case Law?, July 2008

2359 Guglielmo Maria Caporale, Davide Ciferri and Alessandro Girardi, Are the Baltic Countries Ready to Adopt the Euro? A Generalised Purchasing Power Parity Approach, July 2008

2360 Erkki Koskela and Ronnie Schöb, Outsourcing of Unionized Firms and the Impacts of Labour Market Policy Reforms, July 2008

2361 Francisco Alvarez-Cuadrado and Ngo Van Long, A Permanent Income Version of the Relative Income Hypothesis, July 2008

2362 Gabrielle Demange, Robert Fenge and Silke Uebelmesser, Financing Higher Education and Labor Mobility, July 2008

2363 Alessandra Casarico and Alessandro Sommacal, Labor Income Taxation, Human Capital and Growth: The Role of Child Care, August 2008

2364 Antonis Adam, Manthos D. Delis and Pantelis Kammas, Fiscal Decentralization and Public Sector Efficiency: Evidence from OECD Countries, August 2008

2365 Stefan Voigt, The (Economic) Effects of Lay Participation in Courts - A Cross-Country Analysis, August 2008 